\title{
USUL PENELITIAN
}

HIBAH BERSAING

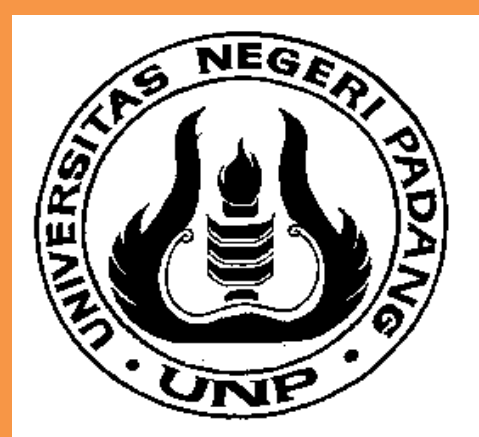

PENGEMBANGAN MODEL PENDIDIKAN PEMILIH

(VOTER'S EDUCATION) BAGI PEMILIH PEMULA

DALAM MEMBANGUN RASIONALISASI PERILAKU MEMILIH DI KOTA PADANG

DRS. SURYANEF, M.Si. (NIDN. 0006066407) DR. FATMARIZA H., M.Hum. (NIDN 0001036606 )

\section{UNIVERSITAS NEGERI PADANG}

MEI 2013 
HALAMAN PENGESAHAN PENELITIAN HIBAH BERSAING

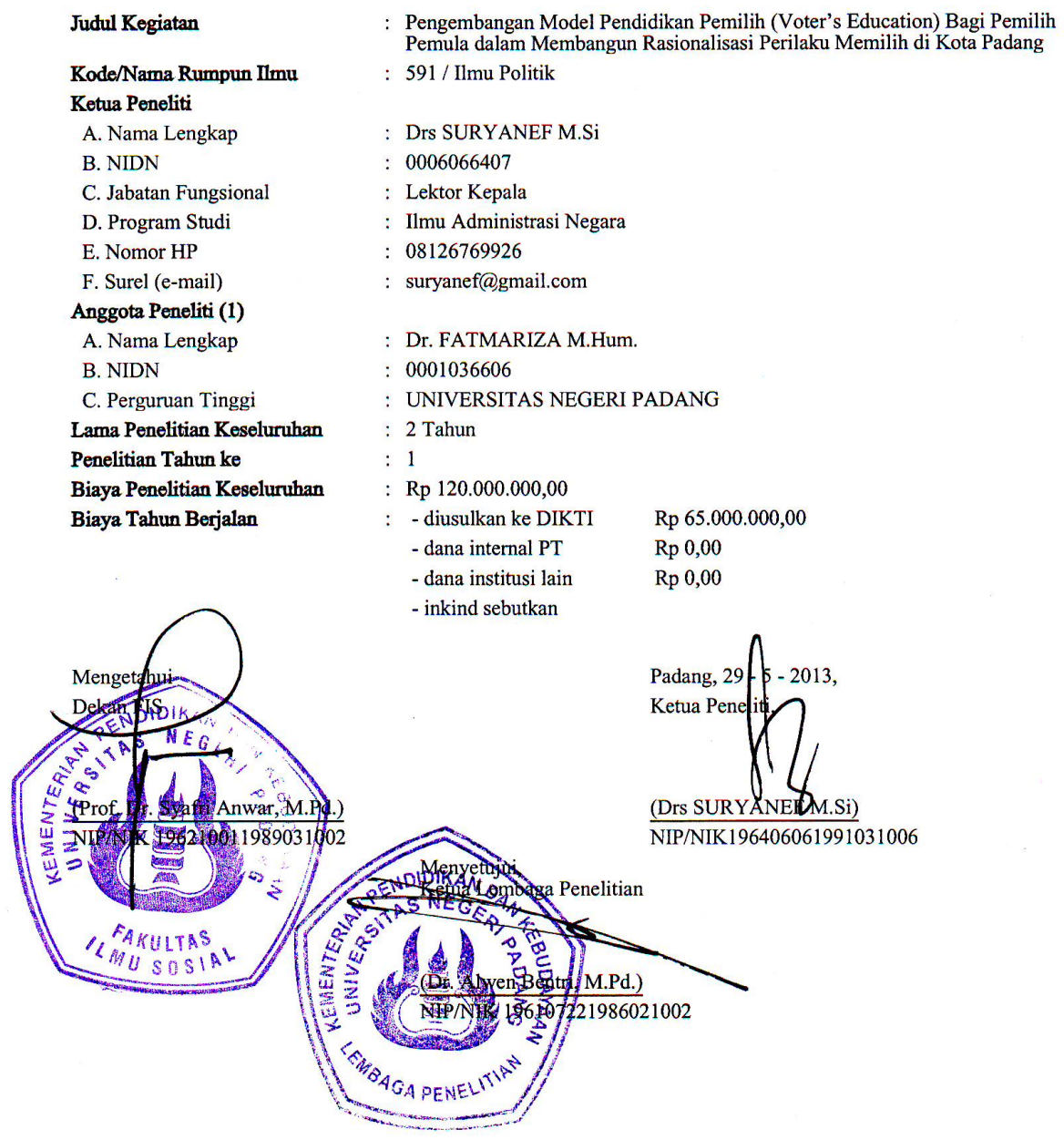




\section{DAFTAR ISI}

\section{HALAMAN PENGESAHAN}

DAFTAR ISI

i

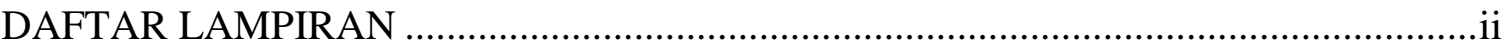

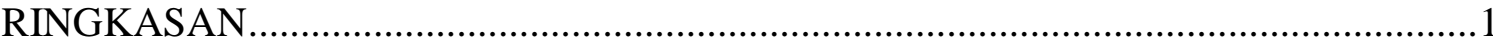

BAB I PENDAHULUAN

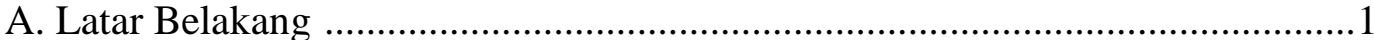

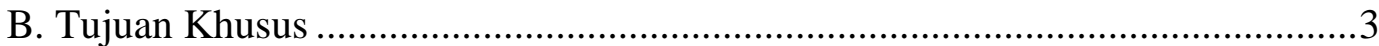

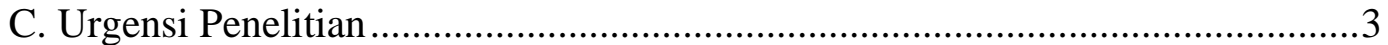

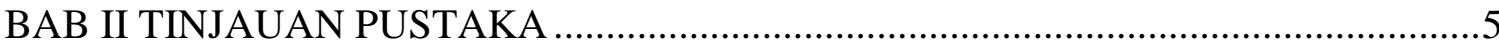

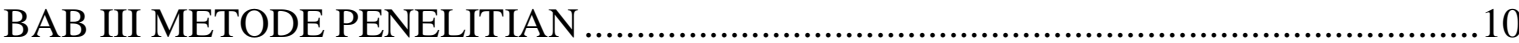

BAB IV BIAYA DAN JADWAL PENELITIAN

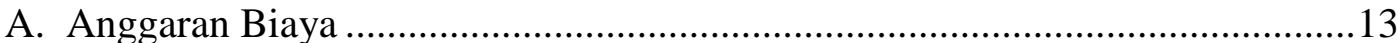

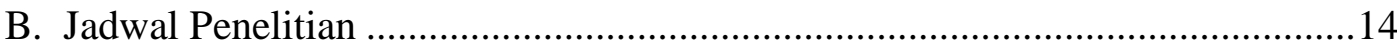

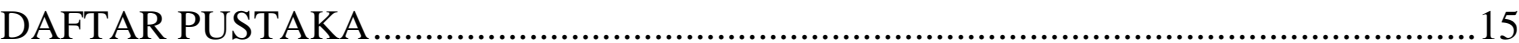

LAMPIRAN-LAMPIRAN 


\section{DAFTAR LAMPIRAN}

Lampiran $1 \quad$ Justifikasi anggaran penelitian

Lampiran 2 Dukungan sarana dan prasarana penelitian

Lampiran 3 Susunan organisasi tim peneliti dan pembagian tugas

Lampiran $4 \quad$ Biodata ketua dan anggota peneliti

Lampiran $5 \quad$ Surat pernyataan ketua peneliti 


\section{RINGKASAN}

Pemilih pemula merupakan unsur pasar potensial bagi partai politik ataupun kandidat dalam pemilihan umum (pemilu). Besarnya jumlah pemilih pemula dari satu pemilu ke pemilu berikutnya sejatinya menjadi sorotan penuh bagi para pihak dalam merebut suara. Sayangnya proses edukasi yang dilakukan terhadap kelompok ini belum menampakkan sistem pendidikan pemilih pemula yang komprehensif dan memberikan dampak bagi perilaku memilih yang kritis dan rasional (ciritical and rational voters). Untuk itu tujuan penelian tahun I adalah : (1) menganalisis berbagai bentuk pendidikan pemilih bagi pemilih pemula yang telah dilaksanakan oleh Komisi Pemilihan Umum Daerah (KPUD), partai politik, atau kelompok-kelompok masyarakat lainnya seperti Lembaga Swadaya Masyarakat (LSM) dari segi strategi, materi, maupun metode pelaksanaannya ; (2) merekonstruksikan model pendidikan pemilih (voter's education) bagi pemilih pemula dalam membangun rasionalisasi perilaku memilih ; dan (3) menghasilkan buku saku pendidikan pemilih bagi pemilih pemula yang akan didesiminasikan kepada pemilih pemula dan juga sekolah-sekolah menengah dalam lingkup Kota Padang.

Sementara itu pada tahun II bertujuan untuk : (1) melakukan sosialisasi model pendidikan pemilih (voter's education) bagi pemilih pemula yang meliputi strategi, materi, dan metode kepada tiga lembaga yaitu KPUD, partai politik, dan pihak sekolah ; (2) melakukan uji kelayakan pengembangan model pendidikan pemilih (voter's education) bagi pemilih pemula melalui review pakar; dan (3) menghasilkan revisi pengembangan model pendidikan pemilih (voter's education) bagi pemilih pemula serta buku saku pendidikan pemilih yang akan didesiminasikan kepada pemilih pemula dan sekolah-sekolah menengah dalam lingkup Kota Padang.

Kata kunci: pendidikan pemilih, pemilih pemula, perilaku pemilih, rational choice

\section{BAB I. PENDAHULUAN}

\section{A. Latar Belakang.}

Pemilih pemula merupakan pemilih yang cukup potensial dan signifikan bagi besaran perolehan suara partai politik pada pemilihan umum (pemilu). Jika dirujuk dari segi angka, terlihat dalam setiap pemilu jumlahnya cukup besar. Dalam pemilu 2004 terdapat 50 juta lebih pemilih pemula, pemilu 2009 potensi pemilih pemula mencapai 36 juta lebih. Sementara data Badan Pusat Statistik (BPS) saat ini untuk pemilu 2014 diperkirakan mencapai lebih dari 32 juta penduduk. Walaupun terlihat penurunan dari segi angka, namun penurunan tersebut tetap tidak mempengaruhi signifikansi pemilih pemula sebagai potensi suara yang cukup besar bagi partai politik atau kandidat lainnya dalam pemilu.

Sayangnya potensi yang cukup signifikan tersebut tidak "dimanfaatkan" oleh berbagai pihak dengan memberikan perhatian yang serius pada kelompok ini. 
Direktur Lingkar Madani Indonesia (LIMA) Ray Rangkuti mengatakan bahwa pendidikan pemilih bagi pemilih pemula masih kurang, sehingga memunculkan persepsi bahwa realitas sosial tidak berhubungan dengan sistem politik Indonesia. Ketidakberhasilan meraih potensi pemilih pemula cukup merugikan karena salah satu titik pijak untuk kaderisasi dan meraih dukungan akan semakin memberatkan bagi partai politik dan kandidat dalam kontestasi politik dari waktu ke waktu (Nur Budi Hariyanto dalam Andi Faizal Bakti, 2012).

Kondisi lebih memprihatinkan lagi ketika kita mengenali perilaku memilih pemilih pemula yang memiliki karakter khusus dibandingkan segmen pemilih lainnya. Perilaku pemilih pemula biasanya masih labil, apatis, pengetahuan politiknya kurang dan untuk membedakannya dengan kelompok lainnya adalah pengalaman politik dalam menghadapi pemilu. Preferensi yang dijadikan sandaran dalam melakukan pemilihan cenderung tidak stabil atau mudah berubah-ubah sesuai dengan informasi atau preferensi yang melingkarinya. Tetapi jika pemilih pemula teredukasi melalui proses pendidikan politik ataupun pendidikan pemilih dengan baik, maka perilaku memilihnya pada saat pertamakali memilih biasanya akan diikuti dengan pilihanpilihan berikutnya (Suryanef dan Al Rafni, 2002).

Bila dicermati program pendidikan pemilih yang telah dilakukan oleh Komisi Pemilihan Umum Daerah (KPUD) Kota Padang misalnya dengan seminar sehari maupun pelaksanaan kelas pemilu dirasakan belum maksimal karena materi yang diberikan masih minim dan durasi pelaksanaan yang cuma sehari. Ketua KPUD Kota Padang, Alison dalam sambutannya pada acara seminar sehari Peningkatan Peranserta Masyarakat dalam Pemilu Legislatif 2014 dan Pemilu Kepala Daerah 2013 mengatakan bahwa pendidikan pemilih pada pemilu legislatif 2014 atau pemilukada 2013 di Kota Padang seharusnya tidak hanya dilakukan secara instan oleh partai politik pada waktu-waktu mendekati hari " $H$ " pemilu saja, namun harus berkesinambungan dan sistematis sejak jauh-jauh hari sebelumnya (Laporan KPUD Kota Padang, 2012). Dari fakta tersebut terlihat belum seriusnya partai politik dan KPUD untuk mengadakan pendidikan pemilih sebagai upaya membangun rasionalitas perilaku memilih.

Berdasarkan pemaparan sebelumnya, maka dirasakan urgen untuk dilakukannya penelitian tentang Pengembangan Model Pendidikan Pemilih (Voter's 
Education) Bagi Pemilih Pemula dalam Membangun Rasionalisasi Perilaku Memilih

di Kota Padang.

\section{B. Tujuan Khusus.}

Pada tahun I, tujuan penelitian ini adalah sebagai berikut :

1. Menganalisis berbagai bentuk pendidikan pemilih bagi pemilih pemula yang telah dilaksanakan oleh Komisi Pemilihan Umum Daerah (KPUD), partai politik, atau kelompok-kelompok masyarakat lainnya seperti Lembaga Swadaya Masyarakat (LSM) dari segi strategi, materi, maupun metode pelaksanaannya.

2. Merekonstruksikan model pendidikan pemilih (voter's education) bagi pemilih pemula dalam membangun rasionalisasi perilaku memilih.

3. Menghasilkan buku saku pendidikan pemilih bagi pemilih pemula yang akan didesiminasikan kepada pemilih pemula dan sekolah-sekolah menengah dalam lingkup Kota Padang.

Sementara itu pada tahun II bertujuan untuk :

1. Melakukan sosialisasi model pendidikan pemilih (voter's education) bagi pemilih pemula yang meliputi strategi, materi, dan metode kepada tiga lembaga yaitu KPUD, partai politik, dan pihak sekolah.

2. Melakukan uji kelayakan pengembangan model pendidikan pemilih (voter's education) bagi pemilih pemula melalui review pakar.

3. Menghasilkan revisi pengembangan model pendidikan pemilih (voter's education) bagi pemilih pemula serta buku saku pendidikan pemilih yang akan didesiminasikan kepada pemilih pemula dan sekolah-sekolah menengah dalam lingkup Kota Padang.

\section{Urgensi Penelitian.}

Pemilih pemula adalah pemilih yang baru pertama kali ikut memilih dalam pemilu, baik pemilu legislatif, pemilu kepala daerah, maupun pemilu presiden. UU No.8 tahun 2012 tentang Pemilihan Umum Anggota DPRD, DPD, dan DPR pasal 18 mendefinisikan pemilih adalah warganegara Indonesia yang telah genap berumur 17 tahun atau lebih atau sudah pernah kawin. Berdasarkan definisi tersebut jelaslah bahwa pemilih pemula ikut pemilu pertamakali karena baru memenuhi persyaratan pemilih sesuai dengan peraturan perundang-undangan. 
Pemilih pemula sangat wajar menjadi incaran partai politik karena setidaknya memiliki dua makna penting, yaitu : (1) menjadi medan perebutan suara dalam pemilu ; dan (2) segmen ini menjadi penentu ramai tidaknya rapat umum partai politik yang memiliki makna penting untuk publikasi maupun mempengaruhi calon pemilih lainnya (Adman Nursal, 2004). Pemilih pemula seringkali digambarkan melalui perilaku sebagai berikut : (1) pemilih yang masih labil ; (2) pemilih yang memiliki pengetahuan politik yang relatif rendah ; (3) pemilih yang cenderung didominasi oleh kelompok (peer-group) ; (4) pemilih yang melakukan pilihan karena aspek popularitas partai politik atau calon yang diusulkan partai politik ; (5) pemilih yang datang ke tempat pemungutan suara (TPS) hanya sekadar untuk mendaftarkan atau menggugurkan haknya (Andi Faisal Bakri, dkk., 2012). Dari gambaran tersebut dapat dipahami bahwa pemilih pemula merupakan kelompok masyarakat yang perlu diedukasi terus menerus agar menjadi pemilih yang cerdas dan rasional.

Lebih jauh, Pomper (1975) menyatakan bahwa pemilih pemula diasumsikan mempunyai perilaku politik yang khas. Penelitian voting behavior di Amerika menunjukkan bahwa pemilih pemula lebih tertarik dengan persoalan-persoalan politik dan melakukan tindakan politik yang secara kualitatif berbeda dengan golongangolongan lainnya. Potensi pemilih kelompok ini mempunyai "dua mata". Di satu pihak ia bernilai positif, kalau saja kita dapat memanfaatkannya dengan baik. Tetapi di lain pihak, kelompok ini juga mengandung kerawanan yang berdampak negatif. Profil dari pemilih pemula tersebut juga dilatarbelakangi dari proses sosialisasi politik yang dialami. Sosialisasi adalah proses dimana individu secara pasif menerima nilainilai, sikap-sikap, peranan-peranan dalam masyarakatnya, sekaligus secara aktif mengembangkan pola kemandiriannya untuk menempatkan diri dan berperan dalam masyarakat dimana seseorang itu hidup.

Sementara itu sosialisasi politik menunjuk pada proses pembentukan sikapsikap dan pola tingkah laku politik dan juga merupakan sarana bagi generasi untuk "mewariskan" patokan-patokan dan keyakinan politik kepada generasi sesudahnya (Almond, 1974). Oleh sebab itu diperlukan pengkajian serius tentang pendidikan pemilih (voter's education) bagi pemilih pemula supaya dapat menjadi pemilih yang kritis dan rasional (critical and rational voters), artinya dalam menjatuhkan pilihannya bukan karena faktor popularitas, kesamaan etnis, atau kedekatan emosional 
namun karena rekam jejak, visi, misi, kredibilitas, dan kapasitas calon. Upaya voter's education yang memuat materi, strategi dan metode yang tepat untuk melakukan edukasi merupakan hal yang terpenting dari empowerment bagi warga negara terutama perilaku memilih pemula.

\section{BAB II. TINJAUAN PUSTAKA.}

Pemilih pemula merupakan potensi signifikan bagi kontestan pemilu untuk mendulang suara. Oleh sebab itu untuk meningkatkan kapasitas pemilih pemula diperlukan pendidikan pemilih (voter's education) guna membangun rasionalisasi perilaku memilih. Dalam perspektif sosiologis pembelajaran dan perilaku pemilih pemula berkaitan erat dengan aspek-aspek kemasyarakatan dan lingkungannya. Ada sejumlah instrumen kemasyarakatan seorang individu seperti status sosial ekonomi (pendidikan, jenis pekerjaan, pendapatan dan kelas), agama, etnik atau ras, wilayah tempat tinggal (seperti perkotaan, pedesaan, pesisir, atau pedalaman). Oleh karena itu perspektif sosiologis beranggapan bahwa preferensi politik seseorang terhadap salah satu partai politik merupakan produk dari karakter sosial ekonomi individu yang bersangkutan (Afan Gaffar, 1992).

Sehubungan dengan perspektif sosiologis temuan penelitian Suryanef dan Al Rafni (2002) menjelaskan bahwa sentuhan pendidikan akan menjadikan pemilih untuk selektif dalam menentukan afiliasi politiknya kepada salah satu partai yang ada. Temuan penelitian ini juga diperkuat dengan hasil penelitian Al Rafni dan Suryanef (2002) yang mengungkapkan terdapat korelasi positif yang signifikan antara tingkat pendidikan dengan perilaku memilih dan oleh karenanya dapat dikatakan bahwa pemilih berpendidikan tinggi, maka perilaku memilihnya akan semakin rasional dan aktif, demikian pula sebaliknya.

Kemudian dalam perspektif psikologis, perilaku memilih lebih memfokuskan perhatiannya pada upaya melihat preferensi seseorang mengenai masalah-masalah politik. Pendekatan ini dibangun dari asumsi bahwa penentuan pilihan politik sangat ditentukan oleh pengaruh kekuatan psikologis yang berkembang dalam diri seseorang sebagai produk dari proses sosialisasi. Greenstein dalam Personality and Politics (Polsby, 1975) mengungkapkan fungsi sikap itu yakni : Pertama, sikap merupakan fungsi kepentingan. Artinya, penilaian terhadap suatu objek diberikan berdasarkan motivasi, minat dan kepentingan orang tersebut. Kedua, sikap merupakan fungsi 
penyesuaian diri. Artinya, seseorang bersikap tertentu sesuai dengan keinginan orang itu untuk sama atau tidak sama dengan tokoh yang diseganinya atau kelompok panutan. Ketiga, sikap merupakan fungsi eksternalisasi dari pertahanan diri. Artinya, sikap seseorang itu merupakan upaya untuk mengatasi konflik batin atau tekanan psikis, yang mungkin berwujud mekanisme pertahanan (defence mechanism) dan eksternalisasi diri seperti proyeksi idealisasi, rasionalisasi, dan identifikasi.

Terlepas dari dua pendekatan tersebut, perilaku memilih mempunyai sifat-sifat tertentu. Menurut Anthony Downs ada dua sifat perilaku memilih, yakni pemilih rasional (rational voters) dan pemilih tradisional (traditional voters). Kelompok pertama adalah pemilih yang menggunakan hak pilih atas dasar rasio atau kehendak sendiri tanpa dipengaruhi orang lain. Sedangkan yang kedua adalah pemilih yang menggunakan hak pilih bukan atas dasar kehendak atau kemauan sendiri, melainkan atas dorongan orang lain seperti orang tua, tokoh masyarakat maupun pemerintah.

Selain itu apabila mengacu pada Huntington dan Nelson (1990), perilaku memilih ada dua, yaitu otonom dan mobilisasi. Seperti halnya pemilih rasional, pemilih yang otonom adalah pemilih yang menggunakan hak pilihnya atas dasar dorongan atau motivasi dirinya sendiri. Sedangkan pemilih yang dimobilisasi sama seperti pemilih tradisional, yakni pemilih yang menggunakan hak pilihnya bukan atas dasar kehendak atau kemauan sendiri, melainkan atas dorongan orang lain seperti orang tua, tokoh masyarakat maupun pemerintah.

Dalam perkembangan kedua pendekatan tersebut dikritisi melalui pendekatan pilihan rasional yang dipelopori oleh Anthony Downs (1957). Berdasarkan pendekatan ini, manusia diasumsikan adalah seorang pemilih yang rasional. Individu mengantisipasi setiap konsekuensi yang mungkin muncul dari pilihan-pilihan yang ada. Lalu, dari pilihan-pilihan tersebut, individu akan memilih pilihan yang memberi keuntungan paling besar bagi dirinya. Berhubungan dengan pemilu, melalui pendekatan ini, pemilih diasumsikan mempertimbangkan segala pilihan yang ada, misalnya tiap-tiap partai politik yang ada, tiap-tiap kandidat yang ada dan tiap-tiap kebijakan yang ada. Lalu dilihat untung atau ruginya bagi individu. Pada akhirnya individu akan memilih yang memberi keuntungan paling besar dan kerugian paling kecil bagi dirinya. Menurut pendekatan pilihan rasional, yang menentukan dalam sebuah pemilu bukanlah adanya ketergantungan terhadap ikatan sosial struktural atau 
ikatan partai yang kuat, melainkan hasil penilaian rasional dari warga yang cakap (Efriza, 2012).

Pendekatan rasional mengantarkan kita pada kesimpulan bahwa para pemilih benar-benar rasional. Para pemilih melakukan "penilaian" yang valid terhadap tawaran partai. Pemilih rasional itu memiliki motivasi, prinsip pengetahuan, dan mendapat informasi yang cukup. Tindakan mereka bukanlah karena faktor kebetulan atau kebiasaan, bukan untuk kepentingan sendiri, melainkan untuk kepentingan umum, menurut pikiran dan pertimbangan yang logis.

Ciri-ciri pemberi suara yang rasional meliputi lima hal yaitu : (1) dapat mengambil keputusan bila dihadapkan pada alternatif ; (2) dapat membandingkan apakah sebuah alternatif lebih disukai, sama saja, atau lebih rendah dibandingkan alternatif lain ; (3) menyusun alternatif dengan cara transitif : jika A lebih disukai daripada $\mathrm{B}$, dan lebih baik daripada $\mathrm{C}$, maka A lebih disukai daripada $\mathrm{C}$; (4) memilih alternatif yang tingkat preferensinya lebih tinggi ; dan (5) selalu mengambil keputusan yang sama bila dihadapkan pada alternatif-alternatif yang sama (Efriza, 2012).

Teori pilihan rasional mensyaratkan adanya pemeringkatan pilihan untuk diputuskan oleh individu. Pemeringkatan pilihan tersebut didasarkan kepada pengetahuan individu yaitu pengetahuan untung rugi dari pilihan yang dibuat. Menurut Florina sebagaimana dikutip Asrinaldi (2012) seorang pemilih yang rasional akan mengaitkan tindakan yang dilakukannya dengan kejadian masa lalu (restropektif). Proses restropektif ini membutuhkan informasi terkait dengan partai, kandidat, dan kebijakan yang dievaluasi oleh individu. Semakin banyak informasi yang diperoleh, maka semakin baik hasil evaluasi yang dilakukan. Evaluasi ini dimaksudkan sebagai dasar pembelajaran dan tindakan sebelumnya agar pemilih tidak mengalami kerugian pada masa mendatang.

Pemilih dalam proses demokrasi pada hakikatnya investor yang menanamkan investasi pilihannya terhadap sesuatu yang mengandung kepentingan publik. Pemilih dalam menentukan pilihannya selalu berdasarkan pada rasionalitas. Dalam kaitan ini rasionalitas menurut Efriza (2012) terbagi menjadi tiga macam, yaitu :

1. Pilihan politik tidak terlepas dari faktor sosial. Faktor sosial bukanlah barang baru yang bisa diisi oleh apapun, tapi telah memiliki sebuah keyakinan berupa 
keputusan untuk menjatuhkan pilihannya pada sesuatu yang diyakininya benar. Hal ini karena faktor sosial selalu berhubungan dengan faktor emosional dan pengaruh sosiokultural yang telah melekat sebagai warisan dalam kehidupannya, dan pada hakikatnya, subkultur dalam wilayah politik yang disebut juga kultur politik, mendorong terjadinya tindakan kolektif dengan atau tanpa perangkat demokrasi yang selalu dijadikan alat untuk membentuk dan menanamkan perilaku pemilih dalam menentukan pilihannya.

2. Berhubungan dengan ketersediaan informasi yang ada dan dapat dipahami secara singkat. Informasi merupakan hal penting dalam membentuk pilihan politik lanjutan, dalam konteks riil, pemilih dalam menentukan pilihannya selalu membuat kesimpulan dengan informasi yang sangat terbatas.

3. Pilihan politik selalu berkaitan dengan persepsi yang dimiliki pemilih terhadap calon yang ada selama proses pengenalan berlangsung. Proses itulah yang menumbuhkan dan menciptakan pemaknaan persepsi, baik positif dan negatif, terhadap partai atau kandidat.

Guna membentuk rasionalisasi perilaku memilih dari pemilih pemula diadakan voter's education oleh beberapa komponen seperti partai politik, KPUD, pemerintah, atau organisasi kemasyarakatan lainnya. Pendidikan pemilih (voter's education) bertujuan : (1) menumbuhkan kesadaran politik sejak dini ; (2) mampu menjadi aktor politik dalam lingkungannya ; (3) pendidikan electoral (sistem pemilu) ; (4) pendidikan kewarganegaraan ; (5) prosedur pemilu yang demokratis ; dan (6) akuntabilitas pemilu maupun penyelenggaraan negara.

Lebih lanjut Hess dan Torney sebagaimana dikutip Efriza (2012) menyusun postulat empat buah model sosialisasi yang dapat juga diterapkan dalam pendidikan pemilih (voter's education) yaitu :

1. Model akumulasi (accumulation model). Tambahan harapan terhadap peran politik dilanjutkan dengan penambahan unit-unit pengetahuan. Model proses belajar ini adalah yang paling tegas ; model ini menyatakan semakin banyak informasi yang diperoleh dimasukkan kepada seorang anak, semakin banyak pengetahuan yang diperoleh anak itu. Hal ini bergantung kepada diperolehnya pokok-pokok informasi yang spesifik. 
2. Model alih antar pribadi (interpersonal transfer model). Anak-anak, berkat sosialisasi keluarga dan yang lain, mengembangkan bermacam-macam hubungan dengan tokoh-tokoh penguasa. Anak ini memperluas hubungan itu berdasarkan pengalaman, hingga mencakup semua hubungan berikutnya. Kekuasaan presiden, misalnya, dapat dipahami sebagai sebuah proyeksi kekuasaan yang sama yang diwakili dalam tokoh seorang bapak. Pembentukan sikap politik dengan cara itu sangat sedikit bergantung pada informasi khusus.

3. Model identifikasi (identification model). Anak-anak mengambil sikap dari orang-orang penting yang lebih tua, biasanya ayah atau guru. Anak itu, yang memihak pada tokoh-tokoh seperti itu, mempergunakan mereka untuk membentuk suatu citra diri yang, jika kukuh akan memberikan dasar bagi afiliasi dari kaitan kelompok. Misalnya, anak-anak mengambil pilihan partai politik orang tua mereka, dan banyak diantara mereka berpegangan terus pada afiliasi-afiliasi itu selama sisa hidup mereka meskipun tidak mempunyai banyak pengertian mengenai apakah yang diwakili oleh afiliasi-afiliasi ini ketika pertamakali diindoktrinasi.

4. Model perkembangan kognitif (cognitive-development model). Proses berpikir anak didasarkan pada pemahaman konseptual mengenai ketertiban yang mengizinkannya untuk menerjemahkan pengertian mengenai tokoh individual menjadi suatu pengertian mengenai individu-individu yang serupa dan mengenai peran mereka dalam sebuah sistem politik. Menjamin pertumbuhan dalam pengertian konseptual, merupakan masalah pendidikan warganegara, yang seharusnya tidak sekadar mengindoktrinasi murid-murid dengan sikap yang "benar" terhadap pemimpin-pemimpin politik, atau terhadap warganegara, atau masyarakat tetapi terutama dalam sebuah masyarakat demokratis, adalah memperbesar kemampuan kognitif untuk memahami isuisu dan politik dalam pengertian jaringan. Model ini bergantung pada perkembangan kemampuan untuk abstraksi.

Untuk kepentingan penelitian ini, tim peneliti telah melakukan studi pendahuluan yang telah dilaksanakan dan sedang dilaksanakan dalam bentuk tabel roadmap penelitian. 


\begin{tabular}{|c|c|c|c|c|}
\hline No. & Tahun & Judul Penelitian & $\begin{array}{l}\text { Hasil penelitian yang } \\
\text { diperoleh/ } \\
\text { akan diperoleh }\end{array}$ & $\begin{array}{c}\text { Relevansi dengan } \\
\text { penelitian yang diajukan }\end{array}$ \\
\hline 1. & 2001 & $\begin{array}{l}\text { Faktor-faktor yang } \\
\text { Mempengaruhi Perilaku } \\
\text { Memilih Generasi } \\
\text { Muda dalam Pemilu } \\
1997 \text { : Kasus di Kota } \\
\text { Padang. }\end{array}$ & $\begin{array}{l}\text { Faktor dominan yang } \\
\text { mempengaruhi perilaku } \\
\text { memilih generasi muda } \\
\text { adalah pemahaman } \\
\text { politik dan identifikasi } \\
\text { kepartaian. }\end{array}$ & $\begin{array}{l}\text { Perlu ditinjau pentingnya } \\
\text { rasionalisasi pemilih bagi } \\
\text { pemilih pemula (generasi } \\
\text { muda). }\end{array}$ \\
\hline 2. & 2002 & $\begin{array}{l}\text { Perilaku Pemberian } \\
\text { Suara Pada Pemilu } \\
1999 \text { Ditinjau dari } \\
\text { Struktur Sosial Pemilih } \\
\text { di Kota Padang. }\end{array}$ & $\begin{array}{l}\text { Terdapatnya hubungan } \\
\text { yang signifikan antara } \\
\text { tingkat pendidikan } \\
\text { pemilih dengan perilaku } \\
\text { pemberian suaranya } \\
\text { dalam pemilu } 1999 .\end{array}$ & $\begin{array}{l}\text { Rasionalisasi pemilih dari } \\
\text { segmen generasi muda } \\
\text { merupakan faktor penentu } \\
\text { mereka untuk melakukan } \\
\text { voting. }\end{array}$ \\
\hline 3. & 2003 & $\begin{array}{l}\text { Pelaksanaan Kampanye } \\
\text { Pemilu } 1999 \text { dan } \\
\text { Implikasinya Terhadap } \\
\text { Perilaku Memilih } \\
\text { Masyarakat Kota } \\
\text { Padang. }\end{array}$ & $\begin{array}{l}\text { Kinerja juru kampanye } \\
\text { tidak mempengaruhi } \\
\text { minat publik untuk } \\
\text { memilih partai. Ada } \\
\text { alasan lain yang } \\
\text { mempengaruhi perilaku } \\
\text { memilih, seperti } \\
\text { identifikasi kepartaian, } \\
\text { status sosial ekonomi, } \\
\text { serta dimensi psikologis } \\
\text { lainnya. }\end{array}$ & $\begin{array}{l}\text { Ada faktor lain di luar } \\
\text { kampanye yang } \\
\text { mempengaruhi perilaku } \\
\text { memilih generasi muda } \\
\text { ataupun segmen pemilih } \\
\text { lainnya. }\end{array}$ \\
\hline 4. & 2004 & $\begin{array}{l}\text { Pemahaman Politik dan } \\
\text { Identifikasi Kepartaian } \\
\text { Perempuan Serta } \\
\text { Kontribusinya } \\
\text { Terhadap Perilaku } \\
\text { Memilih (Kasus Pemilu } \\
1999 \text { di Kota Padang). }\end{array}$ & $\begin{array}{l}\text { Pemahaman politik } \\
\text { masih superfisial } \\
\text { sementara identifikasi } \\
\text { kepartaiannya lebih } \\
\text { cenderung ke arah yang } \\
\text { kuat. }\end{array}$ & $\begin{array}{l}\text { Diperlukan pengkajian } \\
\text { pemahaman politik agar } \\
\text { pemilih mempunyai } \\
\text { kecenderungan perilaku } \\
\text { memilih yang rasional. }\end{array}$ \\
\hline 5. & 2011 & $\begin{array}{l}\text { Pemetaan Orientasi } \\
\text { Politik dan Perilaku } \\
\text { Pemberian Suara } \\
\text { Perempuan dalam } \\
\text { Pemilu Legislatif } 2009 \\
\text { di Kota Padang. }\end{array}$ & $\begin{array}{l}\text { Orientasi politik } \\
\text { perempuan masih } \\
\text { superfisial dan suara } \\
\text { yang diberikan bukan } \\
\text { diutamakan kepada } \\
\text { partai yang peduli } \\
\text { dengan isu-isu } \\
\text { perempuan. }\end{array}$ & $\begin{array}{l}\text { Perlu peningkatan } \\
\text { kapasitas politik dan } \\
\text { perluasan partisipasi politik } \\
\text { perempuan. }\end{array}$ \\
\hline
\end{tabular}

\section{BAB III. METODE PENELITIAN.}

Penelitian ini merupakan kajian pengembangan terhadap model pendidikan pemilih (voter's education). Hal ini sebagai salah satu upaya membangun rasionalisasi perilaku memilih terutama di kalangan pemilih pemula. Oleh karena itu 
metode penelitian yang digunakan adalah metode Research and Development ( $R \& D)$ (Sugiyono, 2010).

Pada tahun I penelitian akan dilakukan beberapa hal berikut : (1) menganalisis berbagai bentuk pendidikan pemilih bagi pemilih pemula yang telah dilaksanakan oleh Komisi Pemilihan Umum Daerah (KPUD), partai politik, atau kelompokkelompok masyarakat lainnya seperti Lembaga Swadaya Masyarakat (LSM) dari segi strategi, materi, maupun metode pelaksanaannya ; (2) merekonstruksikan model pendidikan pemilih (voter's education) bagi pemilih pemula dalam membangun rasionalisasi perilaku memilih ; dan (3) menghasilkan buku saku pendidikan pemilih bagi pemilih pemula yang akan didesiminasikan kepada pemilih pemula dan sekolahsekolah menengah lingkup Kota Padang.

Kemudian pada tahun II yang akan dilakukan adalah : (1) melakukan sosialisasi model pendidikan pemilih (voter's education) bagi pemilih pemula yang meliputi strategi, materi, dan metode kepada tiga lembaga yaitu KPUD, partai politik, dan pihak sekolah ; (2) melakukan uji kelayakan pengembangan model pendidikan pemilih (voter's education) bagi pemilih pemula melalui review pakar ; dan (3) menghasilkan revisi pengembangan model pendidikan pemilih (voter's education) bagi pemilih pemula serta buku saku pendidikan pemilih yang akan didesiminasikan kepada pemilih pemula dan sekolah-sekolah menengah dalam lingkup Kota Padang. Untuk lebih lengkapnya dapat dipaparkan dalam bagan alur dan alir penelitian (fishbone diagram) sebagaimana terdapat pada halaman berikut : 


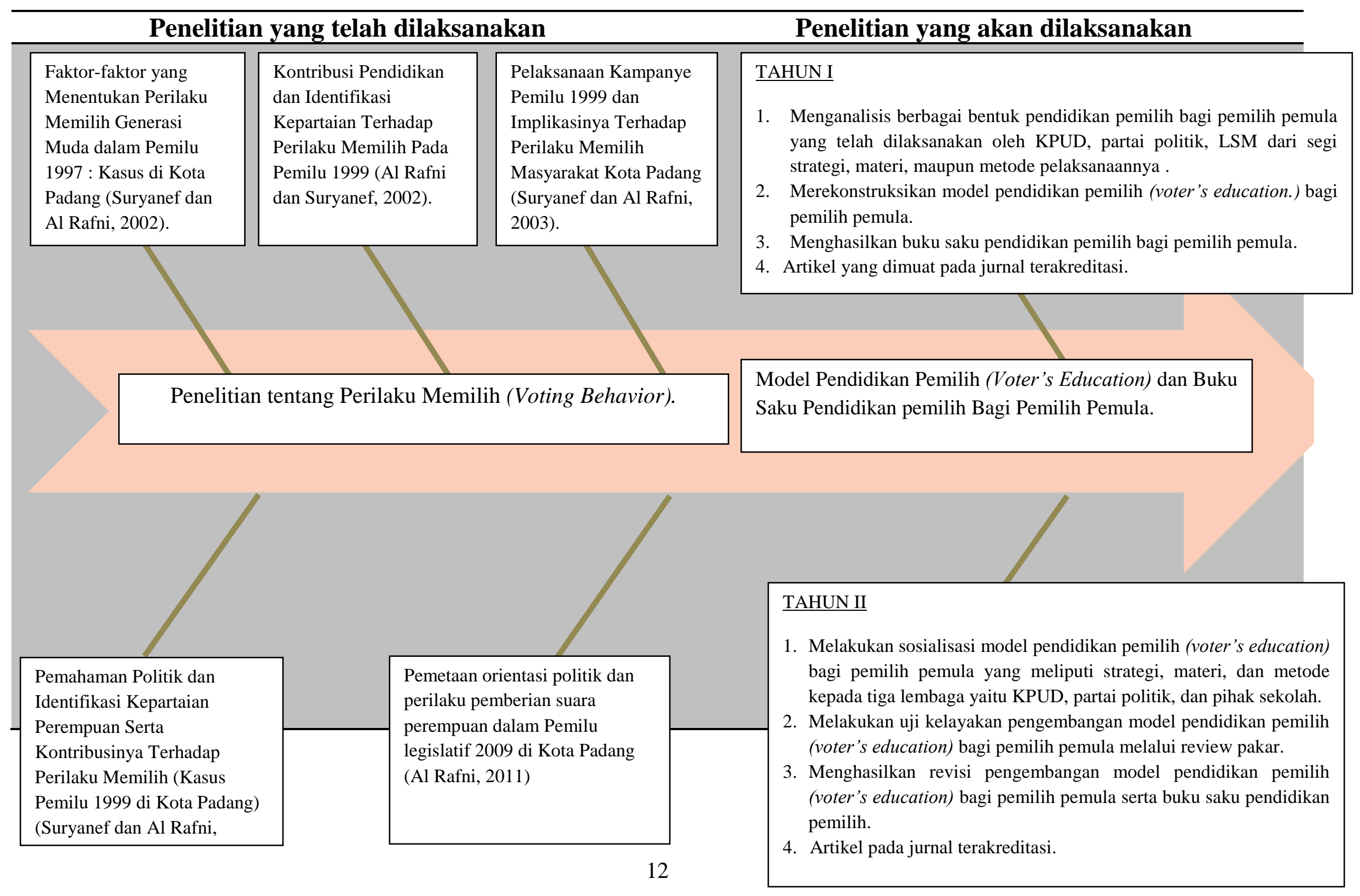


Data penelitian diambil melalui teknik wawancara, observasi, dan studi dokumenter. Adapun langkah-langkah penyusunan model pendidikan pemilih (voter's education) dan buku saku yang bakal dihasilkan dilakukan melalui metode $R \& D$, yang dapat didesain sebagaimana terlihat pada diagram berikut ini.

Diagram : Langkah-langkah Penyusunan Model Metode R\&D hasil adaptasi (Sugiyono, 2010).
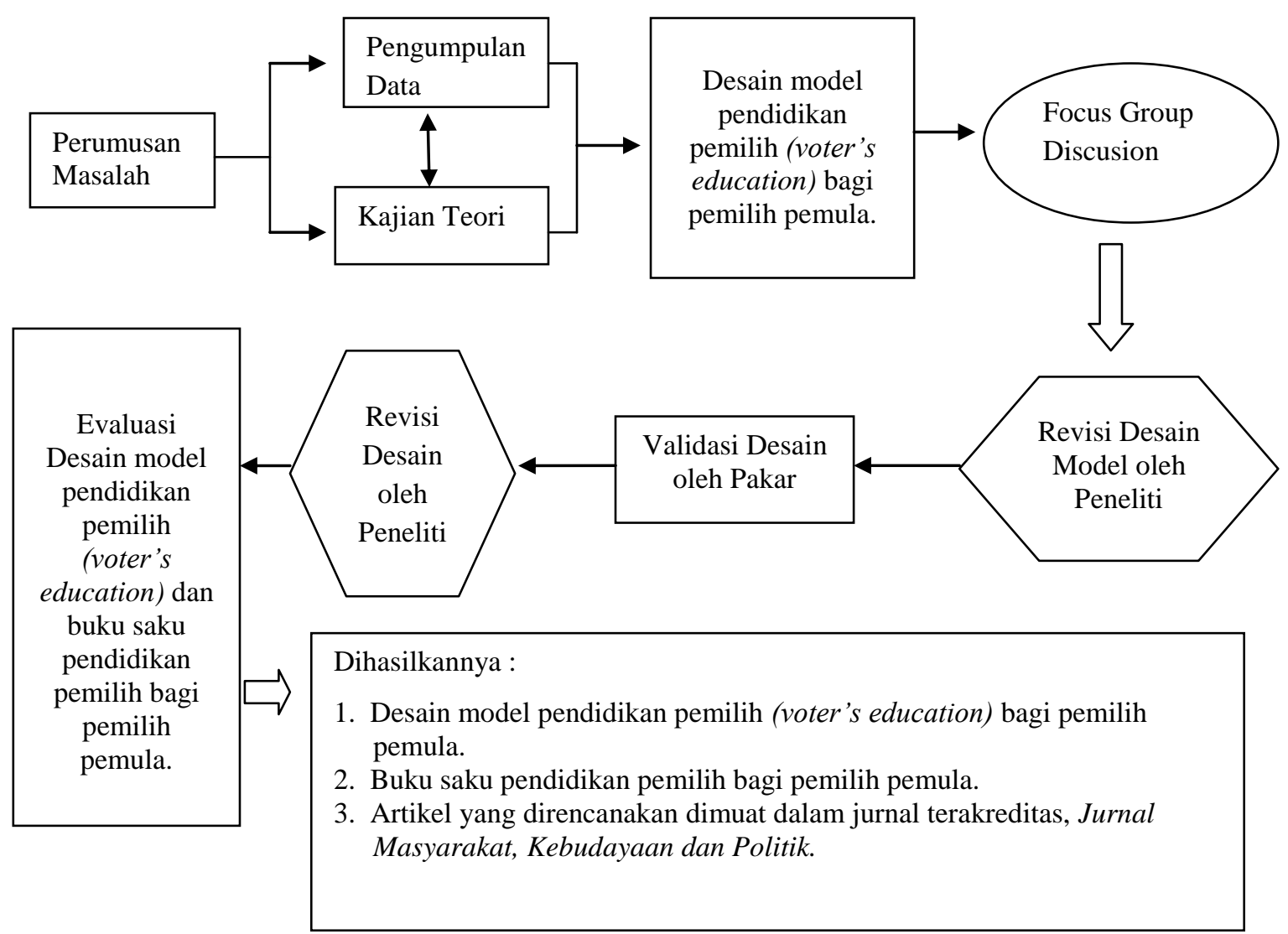

Sementara informan penelitian diambil berdasarkan purposive sampling yaitu dari unsur -unsur berikut : (1) pengurus partai politik ; (2) KPUD ; (3) LSM; dan (4) kalangan pemilih pemula. Untuk lebih jelasnya berikut ini dipaparkan bagan dari tahapan pelaksanaan penelitian yang dirancang dua tahun pelaksanaan, sebagai berikut : 
Tahun I (40\%)

1. Menganalisis berbagai bentuk pendidikan pemilih bagi pemilih pemula yang telah dilaksanakan oleh Komisi Pemilihan Umum Daerah (KPUD), partai politik, atau kelompok-kelompok masyarakat lainnya seperti Lembaga Swadaya Masyarakat (LSM) dari segi strategi, materi, maupun metode pelaksanaannya .

2. Merekonstruksikan model pendidikan pemilih (voter's education) bagi pemilih pemula dalam membangun rasionalisasi perilaku memilih.

3. Menghasilkan buku saku pendidikan pemilih bagi pemilih pemula yang akan didesiminasikan kepada pemilih pemula dan juga sekolah-sekolah menengah dalam lingkup Kota Padang.

4. Artikel yang dimuat pada jurnal terakreditasi (Jurnal Masyarakat, Kebudayaan dan Politik).

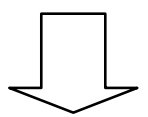

Tahun II (60\%)

1. Melakukan sosialisasi model pendidikan pemilih (voter's education) bagi pemilih pemula yang meliputi strategi, materi, dan metode kepada tiga lembaga yaitu KPUD, partai politik, dan pihak sekolah.

2. Melakukan uji kelayakan pengembangan model pendidikan pemilih (voter's education) bagi pemilih pemula melalui review pakar.

3. Menghasilkan revisi pengembangan model pendidikan pemilih (voter's education) bagi pemilih pemula serta buku saku pendidikan pemilih yang akan didesiminasikan kepada pemilih pemula dan sekolah-sekolah menengah dalam lingkup Kota Padang.

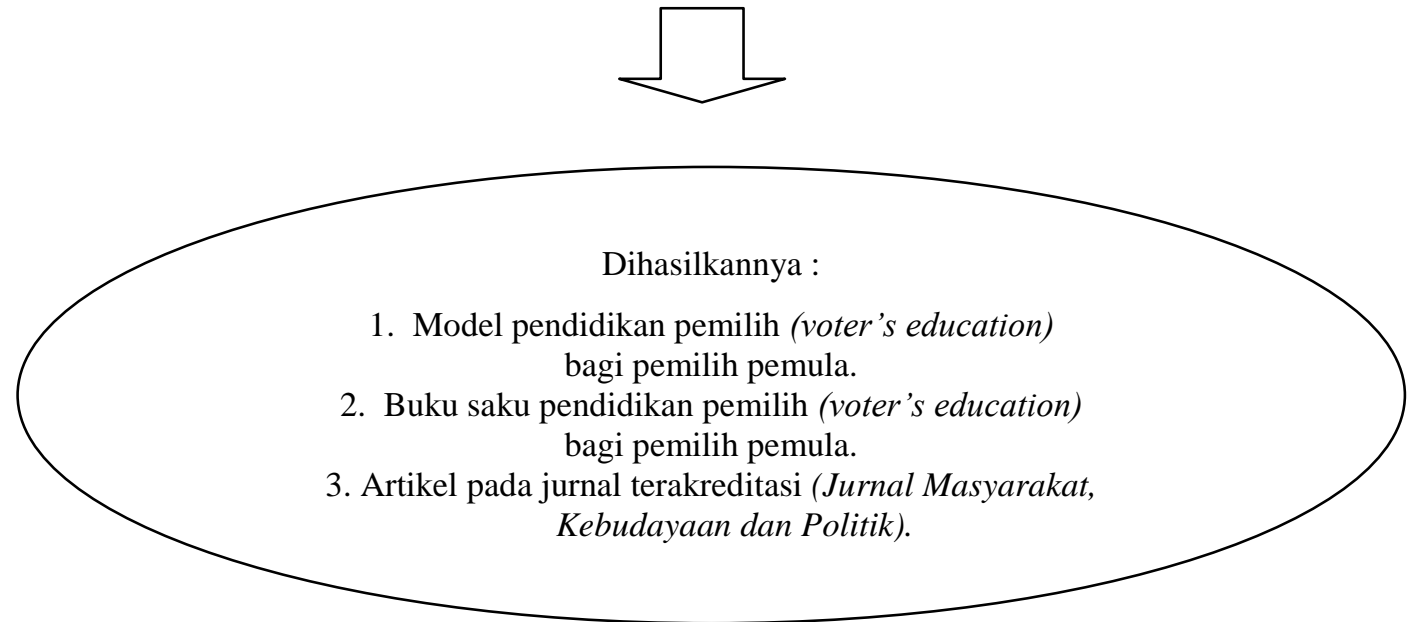




\section{BAB IV. BIAYA DAN JADWAL PELAKSANAAN}

Berikut ini rekapitulasi anggaran penelitian untuk dua tahun:

\begin{tabular}{|c|l|r|r|}
\hline \multirow{2}{*}{ No } & \multicolumn{1}{|c|}{ Jenis Pengeluaran } & \multicolumn{2}{c|}{ Biaya yang Diusulkan (Rp x 1000) } \\
\cline { 3 - 4 } & & \multicolumn{1}{c|}{ Tahun I } & \multicolumn{1}{c|}{ Tahun II } \\
\hline 1. & Gaji dan Upah. & $19.600,-$ & $16.500,-$ \\
\hline 2. & $\begin{array}{l}\text { Bahan habis pakai dan kegiatan } \\
\text { penunjang. }\end{array}$ & $19.650,-$ & $19.250,-$ \\
\hline 3. & Perjalanan. & $16.250,-$ & $11.000,-$ \\
\hline 4. & $\begin{array}{l}\text { Pengolahan data, penyusunan laporan, } \\
\text { seminar hasil, dan publikasi ilmiah. }\end{array}$ & $9.500,-$ & $8.250,-$ \\
\hline \multicolumn{2}{|l}{ Total Anggaran } & $\mathbf{6 5 . 0 0 0 , -}$ & $\mathbf{5 5 . 0 0 0 , -}$ \\
\hline
\end{tabular}

Penelitian ini dilaksanakan dalam jangka waktu dua tahun. Tahun pertama dimulai setelah Penandatanganan Surat Perjanjian Pelaksanaan Penelitian (SP3) yang diperkirakan sekitar bulan April, dan pelaksanaannya berakhir bulan November. Untuk lebih lengkapnya jadwal pelaksanaan penelitian tertera pada matrik dibawah ini:

\section{TAHUN I}

\begin{tabular}{|c|c|c|c|c|c|c|c|c|c|c|}
\hline \multirow[t]{2}{*}{ No. } & \multirow[t]{2}{*}{ Uraian Kegiatan } & \multicolumn{9}{|c|}{ Bulan ke } \\
\hline & & 1 & 2 & 3 & 4 & 5 & 6 & 7 & 8 & 9 \\
\hline \multirow[t]{3}{*}{1.} & Persiapan penelitian. & & & & & & & & & \\
\hline & a. Pengurusan izin. & & & & & & & & & \\
\hline & b. Penyusunan instrumen. & & & & & & & & & \\
\hline \multirow[t]{4}{*}{2.} & Pelaksanaan penelitian. & & & & & & & & & \\
\hline & a. Pengumpulan data lapangan. & & & & & & & & & \\
\hline & b. Analisis data. & & & & & & & & & \\
\hline & $\begin{array}{l}\text { c. Desain rumusan alternatif } \\
\text { kebijakan dan modul } \\
\text { pemberdayaan politik } \\
\text { perempuan. }\end{array}$ & & & & & & & & & \\
\hline \multirow[t]{5}{*}{3.} & Penyusunan laporan. & & & & & & & & & \\
\hline & a. Menyusun laporan. & & & & & & & & & \\
\hline & b. Seminar hasil. & & & & & & & & & \\
\hline & c. Revisi laporan. & & & & & & & & & \\
\hline & d. Penulisan artikel publikasi. & & & & & & & & & \\
\hline
\end{tabular}


Apabila penelitian dilanjutkan pada tahun kedua maka direncanakan sebagaimana yang dilaksanakan pada tahun pertama. Untuk lebih jelasnya dapat dijabarkan melalui tabel sebagai berikut :

\section{TAHUN II}

\begin{tabular}{|c|c|c|c|c|c|c|c|c|c|c|}
\hline \multirow[t]{2}{*}{ No. } & \multirow[t]{2}{*}{ Uraian Kegiatan } & \multicolumn{9}{|c|}{ Bulan ke } \\
\hline & & 1 & 2 & 3 & 4 & 5 & 6 & 7 & 8 & 9 \\
\hline \multirow[t]{2}{*}{1.} & Persiapan penelitian. & & & & & & & & & \\
\hline & Pengurusan izin. & & & & & & & & & \\
\hline \multirow[t]{6}{*}{2.} & Pelaksanaan penelitian. & & & & & & & & & \\
\hline & $\begin{array}{l}\text { a. Pengumpulan data lapangan } \\
\text { melalui FGD untuk uji } \\
\text { terbatas desain. }\end{array}$ & & & & & & & & & \\
\hline & $\begin{array}{l}\text { b. Revisi desain model oleh } \\
\text { peneliti. }\end{array}$ & & & & & & & & & \\
\hline & c. Validasi desain oleh pakar. & & & & & & & & & \\
\hline & $\begin{array}{l}\text { d. Revisi desain model oleh } \\
\text { peneliti. }\end{array}$ & & & & & & & & & \\
\hline & $\begin{array}{l}\text { e. Evaluasi desain dan rumusan } \\
\text { alternatif kebijakan dan } \\
\text { modul pemberdayaan politik } \\
\text { perempuan melalui review } \\
\text { pakar }\end{array}$ & & & & & & & & & \\
\hline \multirow[t]{5}{*}{3.} & Penyusunan laporan. & & & & & & & & & \\
\hline & $\begin{array}{l}\text { a. Menyusun laporan dan } \\
\text { modul.. }\end{array}$ & & & & & & & & & \\
\hline & b. Seminar hasil. & & & & & & & & & \\
\hline & c. Revisi laporan dan modul. & & & & & & & & & \\
\hline & d. Penulisan artikel publikasi. & & & & & & & & & \\
\hline
\end{tabular}

\section{DAFTAR PUSTAKA.}

Adman Nursal. (2004). Political Marketing Strategi Memenangkan Pemilu : Sebuah Pendekatan Baru Kampanye Pemilihan DPR, DPD, Presiden. Jakarta : PT. Gramedia Pustaka Utama.

Afan Gaffar. (1992). Javanese Voters : A Case Study of Election Under A Hegemonic Party System. Yogyakarta : Gadjah Mada Unioversity Press.

Al Rafni dan Suryanef. (2002). Perilaku Pemberian Suara Pada Pemilu 1999 Ditinjau Dari Struktur Sosial Pemilih. Laporan Penelitian - Lembaga Penelitian Universitas Negeri Padang.

Almond, Grabiel A. \& Sidney Verba. (1974). Comparative Politics Today. Boston : Little Brown and Co.

Asrinaldi. (2012). Politik Masyarakat Miskin Kota. Yogyakarta : Gava Media. 
Efriza. (2012). Political Explore : Sebuah Kajian Ilmu Politik. Bandung : Alfabeta.

Greenstein, Fred I. "Personality and Politics" dalam Fred I. Greenstein \& Nelson W. Polsby. (1975). Micro Political Theory : Handbook of Political Science Vol.2. Addison-Wesley Publishing Company.

Laporan KPUD Kota Padang. (2013). Seminar Sehari Peningkatan Peranserta Masyarakat dalam Pemilu 2014 dan Pilkada Kota Padang 2013.

Nur Budi Hariyanto. "Literasi Politik Pemilih Pemula" dalam Andi Faisal Bakti, dkk. (2012). Literasi Politik dan Konsolidasi Politik. Jakarta : Churia Press.

Pomper, Gerald. (1975). Voter's Choice : Varieties of American Electoral Behavior. New York : Doad, Mead Company.

Sugiyono. (2010). Metode Penelitian Kuantitatif, Kualitatif dan R\&D. Bandung : Alfabeta.

Suryanef dan Al Rafni. (2002). Faktor-faktor yang Menentukan Perilaku Memilih Generasi Muda dalam Pemilu 1997 (Kasus di Kota Padang). Laporan Penelitian - Lembaga Penelitian Universitas Negeri Padang. 


\section{Lampiran 1. Justifikasi Anggaran Penelitian}

Biaya penelitian yang diajukan pada tahun pertama berjumlah Rp. 65.000.000,(Enam puluh lima juta rupiah) dengan rincian penggunaan sebagai berikut :

\begin{tabular}{|c|c|c|c|c|c|}
\hline No. & Jenis Anggaran & Satuan & Volume & $\begin{array}{l}\text { Satuan Biaya } \\
\text { (Rp.) }\end{array}$ & $\begin{array}{l}\text { Jumlah Biaya } \\
\text { (Rp.) }\end{array}$ \\
\hline \multirow[t]{4}{*}{1.} & Gaji/Upah. & & & & \\
\hline & 1.1 Ketua Peneliti (1 orang) & OB & 8 & 950.000 & 7.600 .000 \\
\hline & 1.2 Anggota Peneliti (2 orang) & OB & 16 & 750.000 & 12.000 .000 \\
\hline & Jumlah Total 1 & & & & 19.600 .000 \\
\hline \multirow{14}{*}{2.} & & & & & \\
\hline & Bahan dan Kegiatan Penunjang. & & & & \\
\hline & $2.1 \quad$ Kertas HVS & rim & 2 & 30.000 & 60.000 \\
\hline & 2.2 Cartridge HP Laser Jet 1020 & buah & 2 & 750.000 & 1.500 .000 \\
\hline & 2.3 CD-RW & buah & 5 & 10.000 & 50.000 \\
\hline & 2.4 Kaset Maxell C-90 & buah & 50 & 10.000 & 500.000 \\
\hline & $\begin{array}{l}2.5 \text { Penyusunan dan Penggandaan } \\
\text { instrumen. }\end{array}$ & keg. & 1 & 1.000 .000 & 1.000 .000 \\
\hline & 2.6 Baterai & kotak & 3 & 30.000 & 90.000 \\
\hline & 2.7 Seminar Proposal & keg. & 1 & 2.000 .000 & 2.000 .000 \\
\hline & 2.8 Biaya komunikasi & orang & 3 & 500.000 & 1.500 .000 \\
\hline & 2.9 Pengurusan izin penelitian & keg. & 1 & 750.000 & 750.000 \\
\hline & 2.10 Studi penjajakan & keg. & 2 & 1.000 .000 & 2.000 .000 \\
\hline & 2.11 FGD & keg. & 5 & 2.040 .000 & 10.200 .000 \\
\hline & Jumlah Total 2 & & & & 19.650 .000 \\
\hline \multirow[t]{4}{*}{3.} & Perjalanan Dinas. & & & & \\
\hline & $\begin{array}{l}\text { 3.1 Pengumpulan data ke lokasi } \\
\text { penelitiaan. }\end{array}$ & keg. & 6 & 2.125 .000 & 12.750 .000 \\
\hline & $\begin{array}{l}\text { 3.5 Transportasi dan akomodasi } \\
\text { Seminar hasil penelitian } \\
\text { (Padang-Jakarta, pp). }\end{array}$ & keg. & 1 & 3.500 .000 & 3.500 .000 \\
\hline & Jumlah Total 3 & & & & 16.250 .000 \\
\hline \multirow[t]{8}{*}{4.} & $\begin{array}{l}\text { Pengolahan data/laporan/seminar } \\
\text { dan lain-lain. }\end{array}$ & & & & \\
\hline & 4.1 Pengolahan data. & keg. & 1 & 2.500 .000 & 2.500 .000 \\
\hline & 4.2 Penyusunan draf laporan akhir. & keg. & 1 & 1.750 .000 & 1.750 .000 \\
\hline & 4.3 Seminar sejawat. & keg. & 1 & 2.000 .000 & 2.000 .000 \\
\hline & 4.4 Revisi laporan akhir. & keg. & 1 & 1.750 .000 & 1.750 .000 \\
\hline & 4.4 Penggandaan laporan akhir. & keg. & 1 & 500.000 & 500.000 \\
\hline & 4.5 Publikasi ilmiah. & keg. & 1 & 1.000 .000 & 1.000 .000 \\
\hline & Jumlah Total 4 & & & & 9.500 .000 \\
\hline & Jumlah Total 1, 2, 3 dan 4 & & & & 65.000 .000 \\
\hline
\end{tabular}

\section{Terbilang : Enam puluh lima juta rupiah.}




\section{Lampiran 2. Susunan Organisasi Tim Peneliti dan Pembagian Tugas.}

\begin{tabular}{|c|c|c|c|c|c|}
\hline $\begin{array}{l}\mathbf{N} \\
\text { o. }\end{array}$ & Nama & NIDN & $\begin{array}{c}\text { Bidang } \\
\text { Ilmu }\end{array}$ & $\begin{array}{l}\text { Alokasi } \\
\text { Waktu }\end{array}$ & Uraian Tugas \\
\hline 1. & Drs. Suryanef, M.Si & 0006066407 & $\begin{array}{l}\text { Ilmu } \\
\text { Politik }\end{array}$ & $\begin{array}{l}10 \mathrm{jam} / \\
\text { minggu }\end{array}$ & $\begin{array}{l}\text { Membantu dalam: } \\
\text { 1. Menyusun instrumen. } \\
\text { 2. Mengumpulkan data. } \\
\text { 3. Mengolah data. } \\
\text { 4. Menganalisis data. } \\
\text { 5. Mendesain rumusan } \\
\text { kebijakan dan modul. } \\
\text { 6. Menyusun laporan. }\end{array}$ \\
\hline 2. & $\begin{array}{l}\text { Dr. Fatmariza H., } \\
\text { M. Hum. }\end{array}$ & 0001036606 & Sosiologi & $\begin{array}{l}10 \mathrm{jam} / \\
\text { minggu }\end{array}$ & $\begin{array}{l}\text { Membantu dalam: } \\
\text { 1. Menyusun instrumen. } \\
\text { 2. Mengumpulkan data. } \\
\text { 3. Mengolah data. } \\
\text { 4. Menganalisis data. } \\
\text { 5. Mendesain rumusan } \\
\text { kebijakan dan modul. } \\
\text { 6. Menyusun laporan. }\end{array}$ \\
\hline
\end{tabular}




\section{Lampiran 3. Ketersediaan Sarana dan Prasarana Penelitian.}

\section{Dukungan pada Pelaksanaan Penelitian}

1. Dukungan aktif yang sedang berjalan : tidak ada.

2. Dukungan yang sedang dalam tahap pertimbangan : tidak ada.

3. Proposal yang sedang direncanakan atau dalam taraf persiapan : tidak ada.

\section{Sarana}

1. Laboratorium

Penelitian ini dapat menggunakan laboratorium berupa :

a. Labor Jurusan Ilmu Sosial Politik FIS UNP.

b. Perpustakaan Jurusan Ilmu Sosial Politik FIS UNP, Perpustakaan Fakultas dan Perpustakaan Pusat Universitas Negeri Padang.

c. Perpustakaan Balitbangda Provinsi Sumatera Barat.

d. Perpustakaan Wilayah Provinsi Sumatera Barat.

e. Pusat Penelitian Pengembangan Wilayah dan Otonomi Daerah Lemlit UNP.

2. Peralatan utama.
a. Ruang kerja kantor $30 \mathrm{~m}^{2}$.
b. Ruang sekretariat $30 \mathrm{~m}^{2}$.
c. Ruang seminar $150 \mathrm{~m}^{2}$.
d. Komputer 4 unit.
e. Akses ke internet.

3. Keterangan tambahan

Lingkungan tempat kerja di Gedung Fakultas Ilmu-ilmu Sosial Universitas Negeri Padang Kampus Universitas Negeri Padang, Jalan Prof. HAMKA Air Tawar Padang, Telepon/Fax. 0751-7055671, E-mail : suryanef@gmail.com 


\section{Lampiran 4. Biodata Ketua dan Anggota}

\section{Biodata Ketua Tim Pengusul}

\section{A. Identitas Diri.}

\begin{tabular}{|c|c|c|}
\hline 1 & Nama Lengkap & Drs. Suryanef, M.Si. \\
\hline 2 & Jabatan Fungsional & Lektor Kepala. \\
\hline 3 & NIP & 196406061991031006. \\
\hline 4 & NIDN & 0006066407. \\
\hline 5 & Tempat dan Tanggal Lahir & Payakumbuh, 06 Juni 1964. \\
\hline 6 & Alamat Rumah & $\begin{array}{l}\text { Perumahan Pondok Pinang C-16 Lubuk Buaya, } \\
\text { Padang } 25173\end{array}$ \\
\hline 7 & Nomor Telepon/Faks/HP & 0751-482731/ 08126769926. \\
\hline 8 & Alamat Kantor & $\begin{array}{l}\text { Fakultas Ilmu Sosial Universitas Negeri Padang, } \\
\text { Jl.Prof.Dr.Hamka Air Tawar Padang }\end{array}$ \\
\hline 9 & Nomor telepon/Faks & 0751-7055671/0751-7055671 \\
\hline 10 & Alamat e-mail & suryanef@gmail.com \\
\hline 11 & Lulusan yang telah dihasilkan & $\mathrm{S} 1=125$ orang \\
\hline 12 & Mata Kuliah yang diampu & $\begin{array}{ll}\text { 1. } & \text { Ilmu Politik. } \\
\text { 2. } & \text { Sistem Politik Indonesia. } \\
\text { 3. } & \text { Demokrasi di Indonesia. } \\
\text { 4. } & \text { Metode Penelitian Sosial. }\end{array}$ \\
\hline
\end{tabular}

\section{B. Riwayat Pendidikan}

\begin{tabular}{|l|l|l|c|}
\hline & \multicolumn{1}{|c|}{ S-1 } & \multicolumn{1}{c|}{ S-2 } & S-3 \\
\hline Nama PT & IKIP Padang & $\begin{array}{l}\text { Universitas Gadjah } \\
\text { Mada, Yogyakarta. }\end{array}$ & - \\
\hline Bidang Ilmu & $\begin{array}{l}\text { Pendidikan } \\
\text { Kewarganegaraan. }\end{array}$ & Ilmu Politik. & - \\
\hline Tahun Masuk & 1984 & 1997 & - \\
\hline Tahun Lulus & 1990 & \multicolumn{1}{|c|}{1999} & - \\
\hline Judul Skripsi/Tesis/Disertasi & $\begin{array}{l}\text { Hubungan Status Sosial } \\
\text { dengan Tingkat } \\
\text { Partisipasi Masyarakat } \\
\text { dalam Pembangunan } \\
\text { Desa di Kenagarian } \\
\text { Simalanggang, } \\
\text { Kabupaten 50 Kota. }\end{array}$ & $\begin{array}{l}\text { Fenentukan } \\
\text { Perilaku Memilih } \\
\text { Generasi Muda } \\
\text { dalam Pemilihan } \\
\text { Umum 1997 di } \\
\text { Kotamadya Padang. }\end{array}$ & \\
\hline Nama Pembimbing/Promotor & $\begin{array}{l}\text { Drs. Syafnil Effendi, } \\
\text { SH. } \\
\text { Drs. Mazzia Luth, MS. }\end{array}$ & $\begin{array}{l}\text { Dr. Riswandha } \\
\text { Imawan. }\end{array}$ & \\
\hline
\end{tabular}




\section{Pengalaman Penelitian}

\begin{tabular}{|c|c|c|c|c|}
\hline \multirow[t]{2}{*}{ No. } & \multirow[t]{2}{*}{ Tahun } & \multirow[t]{2}{*}{ Judul Penelitian } & \multicolumn{2}{|c|}{ Pendanaan } \\
\hline & & & Sumber & $\begin{array}{c}\text { Jumlah } \\
\text { (Juta Rp.) }\end{array}$ \\
\hline 1. & 2013 & $\begin{array}{l}\text { Strategi Perluasan Akses Perempuan } \\
\text { Terhadap Pendidikan Menengah di } \\
\text { Sumatera Barat. (Ketua Peneliti). }\end{array}$ & $\begin{array}{l}\text { Hibah Bersaing } \\
\text { Tahun II. } \\
\text { (Sedang } \\
\text { berjalan). }\end{array}$ & 45 \\
\hline 2. & 2013 & $\begin{array}{l}\text { Pengembangan Model Pembinaan } \\
\text { Perempuan Kader Partai Oleh Partai Politik } \\
\text { Sebagai Upaya Peningkatan Kualitas } \\
\text { Keterwakilan Perempuan di Lembaga } \\
\text { Legislatif Daerah (Ketua Peneliti). }\end{array}$ & $\begin{array}{l}\text { Hibah Bersaing } \\
\text { Tahun II } \\
\text { (Sedang } \\
\text { berjalan). }\end{array}$ & 45 \\
\hline 3. & 2012 & $\begin{array}{l}\text { Strategi Perluasan Akses Perempuan } \\
\text { Terhadap Pendidikan Menengah di } \\
\text { Sumatera Barat. (Ketua Peneliti). }\end{array}$ & $\begin{array}{l}\text { Hibah Bersaing } \\
\text { Tahun I. }\end{array}$ & 40 \\
\hline 4. & 2012 & $\begin{array}{l}\text { Pengembangan Model Pembinaan } \\
\text { Perempuan Kader Partai Oleh Partai Politik } \\
\text { Sebagai Upaya Peningkatan Kualitas } \\
\text { Keterwakilan Perempuan di Lembaga } \\
\text { Legislatif Daerah (Ketua Peneliti). }\end{array}$ & $\begin{array}{c}\text { Hibah Bersaing } \\
\text { Tahun I }\end{array}$ & 40 \\
\hline 5. & 2011 & $\begin{array}{l}\text { Pemetaan Orientasi Politik dan Perilaku } \\
\text { Pemberian Suara Perempuan dalam Pemilu } \\
\text { Legislatif } 2009 \text { di Kota Padang. } \\
\text { (AnggotaPeneliti). }\end{array}$ & $\begin{array}{c}\text { DIPA } \\
\text { Universitas } \\
\text { Negeri Padang }\end{array}$ & 7,5 \\
\hline 6. & 2010 & $\begin{array}{l}\text { Pemberdayaan Masyarakat Adat sebagai } \\
\text { Basis Penataan Penyelenggaraan } \\
\text { Pemerintahan Nagari di Sumatera Barat. } \\
\text { (Tahun III), (Ketua Peneliti). }\end{array}$ & Hibah Bersaing & 50,25 \\
\hline 7. & 2009 & $\begin{array}{l}\text { Pemberdayaan Masyarakat Adat sebagai } \\
\text { Basis Penataan Penyelenggaraan } \\
\text { Pemerintahan Nagari di Sumatera Barat. } \\
\text { (Tahun II), (Ketua Peneliti). }\end{array}$ & Hibah Bersaing & 50 \\
\hline 8. & 2009 & $\begin{array}{l}\text { Desentralisasi Politik : Kajian Tentang } \\
\text { Pelaksanaan Pemilihan Kepala Daerah } \\
\text { Secara Langsung di Sumatera Barat. } \\
\text { (Anggota Peneliti). }\end{array}$ & $\begin{array}{l}\text { Strategis } \\
\text { Nasional }\end{array}$ & 99 \\
\hline 9. & 2009 & $\begin{array}{l}\text { Evaluasi Nagari Binaan Pilot Proyek Dalam } \\
\text { Rangka Peningkatan Pelaksanaan } \\
\text { Pemerintahan dan Pembangunan di } \\
\text { Sumatera Barat. (Anggota Peneliti). }\end{array}$ & $\begin{array}{c}\text { BAPPEDA } \\
\text { Provinsi } \\
\text { Sumatera Barat. }\end{array}$ & 67,5 \\
\hline 10. & 2008 & $\begin{array}{l}\text { Pemberdayaan Masyarakat Adat sebagai } \\
\text { Basis Penataan Penyelenggaraan } \\
\text { Pemerintahan Nagari di Sumatera Barat. } \\
\text { (Tahun I), (Anggota Peneliti). }\end{array}$ & Hibah Bersaing & 48,5 \\
\hline 11. & 2008 & $\begin{array}{l}\text { Tindak Kekerasan dan Pelecehan Seksual } \\
\text { terhadap Perempuan dan Anak di Sumatera } \\
\text { Barat. (Anggota Peneliti). }\end{array}$ & $\begin{array}{c}\text { Balitbangda } \\
\text { Provinsi } \\
\text { Sumatera Barat. }\end{array}$ & 37,5 \\
\hline 12. & 2007 & Peningkatan Partisipasi Perempuan dalam & Balitbang & 25 \\
\hline
\end{tabular}




\begin{tabular}{|c|c|l|c|c|}
\hline & & $\begin{array}{l}\text { Pendidikan di Nagari-nagari Sumatera } \\
\text { Barat. (Ketua Peneliti). }\end{array}$ & $\begin{array}{c}\text { Depdiknas, } \\
\text { Jakarta. }\end{array}$ & \\
\hline 13. & 2007. & $\begin{array}{l}\text { Perilaku Pemberian Suara, Akses dan } \\
\text { Kontrol Perempuan Etnis Cina (Tionghoa) } \\
\text { dalam Pemilu Legislatif 2004 di Kota } \\
\text { Padang. (Anggota Peneliti). }\end{array}$ & $\begin{array}{c}\text { Diversitas } \\
\text { Negeri Padang. }\end{array}$ & 7,5 \\
\hline
\end{tabular}

\section{Pengalaman Pengabdian Kepada Masyarakat}

\begin{tabular}{|c|c|c|c|c|}
\hline \multirow[t]{2}{*}{ No. } & \multirow[t]{2}{*}{ Tahun } & \multirow[t]{2}{*}{ Judul Pengabdian Kepada Masyarakat } & \multicolumn{2}{|c|}{ Pendanaan } \\
\hline & & & Sumber & $\begin{array}{c}\text { Jumlah } \\
\text { (Juta Rp.) }\end{array}$ \\
\hline 1. & 2012 & $\begin{array}{l}\text { Pelatihan Peningkatan Pemahaman dan } \\
\text { Keterampilan Guru dalam } \\
\text { Mengintegrasikan Pendidikan Karakter } \\
\text { Pada Mata Pelajaran PKn pada Sekolah } \\
\text { Dasar di Kecamatan Lima Kaum Kabupaten } \\
\text { Tanah Datar. }\end{array}$ & $\begin{array}{l}\text { IPTEKS Lokal } \\
\text { (DIPA } \\
\text { Universitas } \\
\text { Negeri Padang). }\end{array}$ & 7,5 \\
\hline 2. & 2012 & $\begin{array}{l}\text { Seminar MGMP dengan Tema "Penguatan } \\
\text { Pembelajaran PKn dalam rangka } \\
\text { Pembangunan Karakter Bangsa". }\end{array}$ & $\begin{array}{l}\text { MGMP Kota } \\
\text { Solok. }\end{array}$ & 10 \\
\hline 3. & 2009 & $\begin{array}{l}\text { Pemberdayaan Masyarakat Adat Nagari } \\
\text { Menuju Akselerasi Pembangunan Nagari . } \\
\text { (Anggota Pelaksana). }\end{array}$ & $\begin{array}{l}\text { IPTEKS Lokal } \\
\text { (DIPA } \\
\text { Universitas } \\
\text { Negeri Padang). }\end{array}$ & 7,5 \\
\hline 4. & 2009 & $\begin{array}{l}\text { Peningkatan Pengetahuan, Kepedulian serta } \\
\text { Keterampilan Perempuan Etnis Cina } \\
\text { (Tionghoa) di Kota Padang dalam } \\
\text { Melakukan Aktifitas Politik. } \\
\text { (Ketua Pelaksana). }\end{array}$ & $\begin{array}{l}\text { IPTEKS } \\
\text { Nasional }\end{array}$ & 10 \\
\hline 5. & 2008 & $\begin{array}{l}\text { Peningkatan Pengetahuan dan } \\
\text { Profesionalisme Aparatur Penyelenggara } \\
\text { Pemerintahan Nagari dan Masyarakat Adat } \\
\text { di Kecamatan X Koto Singkarak Kabupaten } \\
\text { Solok. (Anggota Pelaksana). }\end{array}$ & $\begin{array}{l}\text { IPTEKS Lokal } \\
\text { (DIPA } \\
\text { Universitas } \\
\text { Negeri Padang). }\end{array}$ & 5 \\
\hline 6. & 2008 & $\begin{array}{l}\text { Pendalaman Materi Pembelajaran PKn Bagi } \\
\text { Guru-guru PKn SMP Negeri se-Kabupetan } \\
\text { Tanah Datar Tentang Hak Asasi Manusia. } \\
\text { (Ketua Pelaksana). }\end{array}$ & $\begin{array}{c}\text { MGMP } \\
\text { Kabupaten } \\
\text { Tanah Datar. }\end{array}$ & 3 \\
\hline 7. & 2007 & $\begin{array}{l}\text { Pendalaman Materi Pembelajaran PKn Bagi } \\
\text { Guru-guru PKn SMA Negeri se-Kota } \\
\text { Padang Tentang Dinamika Sistem Politik } \\
\text { Indonesia. (Ketua Pelaksana). }\end{array}$ & $\begin{array}{l}\text { MGMP Kota } \\
\text { Padang. }\end{array}$ & 3 \\
\hline 8. & 2007 & $\begin{array}{l}\text { Pendalaman Materi Pembelajaran PKn Bagi } \\
\text { Guru-guru PKn SMK Negeri se-Kota } \\
\text { Padang Tentang Hak Asasi Manusia dan } \\
\text { Sistem Politik (Ketua Pelaksana). }\end{array}$ & $\begin{array}{l}\text { MGMP Kota } \\
\text { Padang. }\end{array}$ & 3 \\
\hline 9. & 2007 & Pendalaman Materi Pembelajaran PKn Bagi & MGMP & 3 \\
\hline
\end{tabular}




\begin{tabular}{|l|l|l|c|c|}
\hline & $\begin{array}{l}\text { Guru-guru PKn SMP Negeri se-Kabupaten } \\
\text { Tanah Datar Tentang Budaya Politik. } \\
\text { (Ketua Pelaksana). }\end{array}$ & $\begin{array}{c}\text { Kabupaten } \\
\text { Tanah Datar. }\end{array}$ & \\
\hline
\end{tabular}

\section{E. Pengalaman Penulisan Artikel Ilmiah Dalam Jurnal}

\begin{tabular}{|c|c|l|l|l|}
\hline No. & Tahun & \multicolumn{1}{|c|}{ Judul Artikel Ilmiah } & \multicolumn{1}{|c|}{$\begin{array}{c}\text { Volume/ } \\
\text { Nomor }\end{array}$} & \multicolumn{1}{|c|}{ Nama Jurnal } \\
\hline 1. & 2011. & $\begin{array}{l}\text { Pelaksanaan Pilkada Langsung di } \\
\text { Sumatera Barat Ditinjau Dari Perspektif } \\
\text { Desentralisasi Politik (Penulis Utama). } \\
\text { Nomor 1. }\end{array}$ & $\begin{array}{l}\text { Jurnal Analisa } \\
\text { Politik. }\end{array}$ \\
\hline 2. & 2011 & $\begin{array}{l}\text { Pelaksanaan Evaluasi Nagari Binaan Pilot } \\
\text { Proyek di Nagari-nagari Sumatera Barat. } \\
\text { (Mandiri). }\end{array}$ & $\begin{array}{l}\text { Vol.X, No.1, } \\
\text { April 2011. } \\
\cdot\end{array}$ & $\begin{array}{l}\text { Jurnal } \\
\text { Demokrasi. }\end{array}$ \\
\hline 3. & 2008 & $\begin{array}{l}\text { Marjinalisasi dan Pemberdayaan } \\
\text { Masyarakat Adat dalam Penyelenggaraan } \\
\text { Pemerintahan Nagari di Sumatera Barat. } \\
\text { (Penulis Utama). }\end{array}$ & $\begin{array}{l}\text { Vol.VII, No.1, } \\
\text { April 2008. }\end{array}$ & $\begin{array}{l}\text { Jurnal } \\
\text { Demokrasi. }\end{array}$ \\
\hline 4. & 2007 & $\begin{array}{l}\text { Penataan Penyelenggaraan Pemerintahan } \\
\text { Nagari di Sumatera Barat. (Mandiri). }\end{array}$ & $\begin{array}{l}\text { Edisi 02 } \\
\text { Tahun 2007. }\end{array}$ & $\begin{array}{l}\text { Jurnal Balitbang } \\
\text { Provinsi } \\
\text { Sumatera Barat. }\end{array}$ \\
\hline
\end{tabular}

\section{E. Pengalaman Penyampaian Makalah Secara Oral Pada Pertemuan/Seminar Ilmiah}

\begin{tabular}{|c|c|c|c|}
\hline No. & $\begin{array}{c}\text { Nama Pertemuan Ilmiah/ } \\
\text { Seminar }\end{array}$ & Judul Artikel Ilmiah & $\begin{array}{l}\text { Waktu dan } \\
\text { Tempat }\end{array}$ \\
\hline 1. & $\begin{array}{l}\text { Seminar Hasil Penelitian Hibah } \\
\text { Bersaing Tahun } 2012 .\end{array}$ & $\begin{array}{l}\text { Pemberdayaan Masyarakat Adat } \\
\text { Sebagai Basis Penataan } \\
\text { Penyelenggaraan Pemerintahan } \\
\text { Nagari. }\end{array}$ & $\begin{array}{l}\text { Padang, 1-2 Juni } \\
2012 .\end{array}$ \\
\hline 2. & $\begin{array}{l}\text { Seminar Nasional "Strategi dan } \\
\text { Assesment dalam } \\
\text { Meningkatkan Soft Skill } \\
\text { Peserta Didik dalam } \\
\text { Pembelajaran PKn". }\end{array}$ & $\begin{array}{l}\text { Assesment Pembelajaran PKn } \\
\text { dalam Upaya Meningkatkan Sof t } \\
\text { Skill Peserta Didik. }\end{array}$ & $\begin{array}{l}\text { 28 Januari } 2012 . \\
\text { STKIP Abdi } \\
\text { Pendidikan } \\
\text { Payakumbuh. }\end{array}$ \\
\hline 3. & $\begin{array}{l}\text { Seminar Nasional "Wawasan } \\
\text { Kebangsaan dan Kesatuan di } \\
\text { Era Globalisasi", } \\
\text { diselenggarakan LPKP } \\
\text { Sumatera Barat dan } \\
\text { Kementerian Dalam Negeri RI. }\end{array}$ & $\begin{array}{l}\text { Peran Civil Society dalam } \\
\text { Menumbuhkembangkan } \\
\text { Nasionalisme. }\end{array}$ & $\begin{array}{l}29 \text { November 2011, } \\
\text { Pangeran Beach } \\
\text { Hotel. }\end{array}$ \\
\hline 4. & $\begin{array}{l}\text { Seminar Nasional } \\
\text { "Pembelajaran Aktif untuk } \\
\text { Perguruan Tinggi". }\end{array}$ & $\begin{array}{l}\text { Pembelajaran Model Jigsaw } \\
\text { dalam Perkuliahan Pendidikan } \\
\text { Politik. }\end{array}$ & $\begin{array}{l}\text { 5-6 Juli 2010, Hotel } \\
\text { Mulia, Jakarta. }\end{array}$ \\
\hline 5. & $\begin{array}{l}\text { Seminar "Pemilu dan Hak } \\
\text { Asasi Manusia" }\end{array}$ & $\begin{array}{l}\text { Pemilu sebagai } \\
\text { Pengimplementasian Hak-hak }\end{array}$ & $\begin{array}{l}6 \text { April } 2009, \\
\text { Pangeran City }\end{array}$ \\
\hline
\end{tabular}




\begin{tabular}{|c|l|l|l|}
\hline & $\begin{array}{l}\text { diselenggarakan Kanwil } \\
\text { Depkum dan HAM Provinsi } \\
\text { Sumbar. }\end{array}$ & Politik. & Hotel. \\
\hline 6. & $\begin{array}{l}\text { Seminar Nasional Hasil } \\
\text { Penelitian Hibah Bersaing. }\end{array}$ & $\begin{array}{l}\text { Pemberdayaan Masyarakat Adat } \\
\text { di Nagari-nagari Sumatera Barat. }\end{array}$ & $\begin{array}{l}\text { 7-8 April, 2008, } \\
\text { Hotel Millenium, } \\
\text { Jakarta. }\end{array}$ \\
\hline 7. & $\begin{array}{l}\text { Seminar Nasional "Menuju } \\
\text { Pemilu Demokratis", }\end{array}$ & $\begin{array}{l}\text { Kampanye dalam Pemilu yang } \\
\text { Demokratis. }\end{array}$ & $\begin{array}{l}\text { Fakultas Hukum } \\
\text { Universitas Andalas, } \\
\text { 4 Februari 2007. }\end{array}$ \\
\hline
\end{tabular}

\section{F. Pengalaman Penulisan Buku}

\begin{tabular}{|c|c|c|c|c|}
\hline No. & Tahun & Judul Buku & $\begin{array}{c}\text { Jumlah } \\
\text { Halaman }\end{array}$ & Penerbit \\
\hline & & & & \\
\hline
\end{tabular}

\section{G. Pengalaman Perolehan HKI}

\begin{tabular}{|c|c|c|c|c|}
\hline No & Tahun & Judul/Tema HKI & Jenis & NomorP/ID \\
\hline & & & & \\
\hline
\end{tabular}

\section{H. Pengalaman Merumuskan Kebijakan Publik/Rekayasa Sosial Lainnya}

\begin{tabular}{|c|c|c|c|c|}
\hline No. & Tahun & $\begin{array}{c}\text { Judul/Tema/Jenis Rekayasa Sosial } \\
\text { Lainnya yang Telah Diterapkan }\end{array}$ & $\begin{array}{c}\text { Tempat } \\
\text { Penerapan }\end{array}$ & $\begin{array}{c}\text { Respons } \\
\text { Masyarakat }\end{array}$ \\
\hline & & & & \\
\hline
\end{tabular}

\section{Penghargaan Yang Pernah Diraih Dalam 10 Tahun Terakhir} (Dari Pemerintah, Asosiasi atau Institusi Lainnya)

\begin{tabular}{|c|c|c|c|}
\hline No. & Jenis Penghargaan & Institusi Pemberi Penghargaan & Tahun \\
\hline 1. & Dosen Berprestasi I. & $\begin{array}{l}\text { Fakultas Ilmu-ilmu Sosial Universitas } \\
\text { Negeri Padang. }\end{array}$ & 2007. \\
\hline 2. & $\begin{array}{l}\text { Tim Terbaik Pengimplementasian } \\
\text { Pembelajaran Aktif di Perguruan } \\
\text { Tinggi. }\end{array}$ & $\begin{array}{l}\text { Decentralized Basic Education } \\
\text { (DBE)-USAID, Jakarta. }\end{array}$ & 2010 \\
\hline 3. & Peneliti Berprestasi I. & Universitas Negeri Padang. & 2012 \\
\hline 4. & $\begin{array}{l}\text { Poster Terbaik dalam Seminar } \\
\text { Penelitian Hibah Bersaing Tahun } \\
\text { 2012. }\end{array}$ & $\begin{array}{l}\text { DP2M Dirjen Dikti Kementerian } \\
\text { Pendidikan dan Kebudayaan. }\end{array}$ & 2012 \\
\hline
\end{tabular}

Semua data yang saya isikan dan tercantum dalam biodata ini adalah benar dan dapat dipertanggungjawabkan secara hukum. Apabila di kemudian hari ternyata dijumpai ketidaksesuaian dengan kenyataan, saya sanggup menerima resikonya. 
Demikian biodata ini saya buat dengan sebenarnya üntuk memenuhi salah satu persyaratan dalam pengajuan Hibah Penelitian Bersaing.

Padang, 2†ी Mei 2013

Pengusul,

16

Drs. Suryanef, M.Si. 


\section{Biodata Anggota Tim Pengusul.}

\section{A.Identitas Diri}

\begin{tabular}{|l|l|l|}
\hline 1 & Nama lengkap dan Gelar & Dr.Fatmariza.H. M.Hum (P) \\
\hline 2 & Jabatan Fungsional & Lektor kepala \\
\hline 3 & Jabatan Struktural & Ketua Prodi PPKn \\
\hline 4 & NIP & 196603041991032001 \\
\hline 5 & NIDN & 0001036606 \\
\hline 6 & Tempat dan tgl lahir & Pandai Sikat/4 Maret 1966 \\
\hline 7 & Alamat rumah & Komp. Parupuk Raya H/16 Tabing Padang \\
\hline 8 & Nomor Telp/Fax/HP & (0751)40113/08126616704 \\
\hline 9 & Alamat kantor & Jln.Prof.Dr.HAMKA air Tawar Padang \\
\hline 10 & Nomor Telp/Fax & (0751)445187 \\
\hline 11 & Amalat Email & fatmariza@ ymail.com/fatmariza.unp@ gmail.com \\
\hline 12 & Lulusan yang telah & S1=40 orang; S2= \\
& dihasilkan & \\
\hline 13 & Mata Kuliah yang diampu & 1. Pengantar Sosiologi \\
& & 2. Perspektif Gender \\
& & 3. Perencanaan Pembelajaran PPKn \\
& & 4. Kriminologi \\
& & 5. Metodologi Penelitian Kualitatif \\
& & 7. Sosiologi Politik (S2) \\
\end{tabular}

\section{B. Riwayat Pendidikan}

\begin{tabular}{|l|l|l|l|}
\hline & \multicolumn{1}{|c|}{ S1 } & \multicolumn{1}{c|}{ S2 } & \multicolumn{1}{c|}{ S3 } \\
\hline Nama Perguruan Tinggi & IKIP Padang & $\begin{array}{l}\text { Universitas } \\
\text { Indonesia }\end{array}$ & $\begin{array}{l}\text { Universitas } \\
\text { Indonesia }\end{array}$ \\
\hline Bidang Ilmu & PPKn & $\begin{array}{l}\text { Kajian } \\
\text { Wanita/Gender }\end{array}$ & $\begin{array}{l}\text { Sosiologi } \\
\text { (Sosiologi gender) }\end{array}$ \\
\hline Tahun Masuk & 1985 & 1996 & 2008 \\
\hline Tahun Lulus & 1990 & 1999 & 2012 \\
\hline $\begin{array}{l}\text { Judul } \\
\text { Skripsi/Thesis/Diseerrtasi }\end{array}$ & $\begin{array}{l}\text { Penangkapan } \\
\text { dan } \\
\text { penahanan } \\
\text { menurut } \\
\text { KUHAP dari } \\
\text { segi } \\
\text { perlindungan } \\
\text { HAM }\end{array}$ & $\begin{array}{l}\text { Pendidikan } \\
\text { Anak } \\
\text { Perempuan } \\
\text { dalam } \\
\text { Masyarakat } \\
\text { Minangkabau } \\
\text { di Perdesaan }\end{array}$ & $\begin{array}{l}\text { Kembali Ke } \\
\text { Nagari Dan } \\
\text { Reposisi } \\
\text { Perempuan } \\
\text { Minangkabau } \\
\text { dalam Institusi } \\
\text { Nagari }\end{array}$ \\
\hline Nama Pembbg/Promotor & $\begin{array}{l}\text { Sawir Karim- } \\
\text { Yulinar Noer }\end{array}$ & $\begin{array}{l}\text { Siti Hidayati } \\
\text { Amal }\end{array}$ & $\begin{array}{l}\text { Paulus Wirutomo- } \\
\text { Francisia Saveria } \\
\text { Sika Ery Seda }\end{array}$ \\
\hline
\end{tabular}




\section{Pengalaman Penelitian}

\begin{tabular}{|c|c|c|c|c|}
\hline \multirow[t]{2}{*}{ No } & \multirow[t]{2}{*}{ Tahun } & \multirow[t]{2}{*}{ Judul Penelitian } & \multicolumn{2}{|c|}{ Pendanaan } \\
\hline & & & Sumber & $\begin{array}{l}\text { Jml/juta } \\
\mathrm{RP}\end{array}$ \\
\hline 1 & 2013 & $\begin{array}{l}\text { Pemberdayaan Kembali Perempuan } \\
\text { Minang Di Nagari } \\
\text { (Reempowerment of women): } \\
\text { Model Pendekatan Kebijakan } \\
\text { Pembangunan yang responsive } \\
\text { Gender Berbasis Nagari (tahun 2) }\end{array}$ & $\begin{array}{l}\text { Hibah } \\
\text { Bersaing } \\
\text { Dikti }\end{array}$ & 50 \\
\hline 2 & 2012 & $\begin{array}{l}\text { Pemberdayaan Kembali Perempuan } \\
\text { Minang Di Nagari } \\
\text { (Reempowerment of women): } \\
\text { Model Pendekatan Kebijakan } \\
\text { Pembangunan yang responsive } \\
\text { Gender Berbasis Nagari (Tahun 1) }\end{array}$ & $\begin{array}{l}\text { Hibah } \\
\text { Bersaing } \\
\text { Dikti }\end{array}$ & 35 \\
\hline 3 & 2009 & $\begin{array}{l}\text { Perceraian di bawah Tangan dan } \\
\text { implikasinya terhadap perempuan } \\
\text { dalam masyarakat matrilineal } \\
\text { minangkabu. }\end{array}$ & UNP & 5 \\
\hline 4 & 2008 & $\begin{array}{l}\text { Kekerasan dan pelecehan seksual } \\
\text { terhadap perempuan dan anak di } \\
\text { Sumatera Barat }\end{array}$ & $\begin{array}{l}\text { Pemda } \\
\text { Sumbar }\end{array}$ & 45 \\
\hline 5 & 2008 & $\begin{array}{l}\text { Pemberdayaan Perempuan Korban } \\
\text { tindak Kekerasan. } 2008\end{array}$ & $\begin{array}{l}\text { Pemda } \\
\text { Sumbar }\end{array}$ & 25 \\
\hline 6 & 2007 & $\begin{array}{l}\text { Fenomena perkosaan terhadap anak } \\
\text { perempuan dalam masyarakat } \\
\text { Minangkabau di Sumatera Barat }\end{array}$ & DP2M Dikti & 10 \\
\hline 7 & 2006 & $\begin{array}{l}\text { Profil Statistik Gender Dan Analisis } \\
\text { Propinsi Sumatera Barat }\end{array}$ & $\begin{array}{l}\text { Pemda } \\
\text { Sumbar }\end{array}$ & 30 \\
\hline 8 & 2006 & $\begin{array}{l}\text { Peranan Bundo Kanduang dalam } \\
\text { pemberdayaan perempuan Di Kota } \\
\text { Padang }\end{array}$ & $\begin{array}{l}\text { Pemko } \\
\text { Padang }\end{array}$ & 40 \\
\hline 9 & 2004 & $\begin{array}{l}\text { Kekerasan Terhadap Perempuan } \\
\text { dalam Rumah Tangga: Studi } \\
\text { tentang Pandangan Mubalig }\end{array}$ & DP2M Dikti & 10 \\
\hline 10 & 2004 & $\begin{array}{l}\text { Kajian Partisipasi Politik } \\
\text { Perempuan di Sumatra Barat }\end{array}$ & $\begin{array}{l}\text { Biro PP } \\
\text { Sumbar }\end{array}$ & 20 \\
\hline 11 & 2004 & $\begin{array}{l}\text { Analisis Kebijakan Pendidikan } \\
\text { Berwawasan Gender dalam rangka } \\
\text { Penyusunan Kebijakan Pendidikan } \\
\text { Berwawasan Gender di Sumatera } \\
\text { Barat II }\end{array}$ & $\begin{array}{l}\text { Dirjend PLS } \\
\text { Depdiknas }\end{array}$ & 25 \\
\hline
\end{tabular}




\begin{tabular}{|l|l|l|l|l|}
\hline 12 & 2003 & $\begin{array}{l}\text { Analisis Kebijakan Pendidikan } \\
\text { Berwawasan Gender dalam rangka } \\
\text { Penyusunan Kebijakan Pendidikan } \\
\text { Berwawasan Gender di Sumatera } \\
\text { Barat I }\end{array}$ & $\begin{array}{l}\text { Dirjend PLS } \\
\text { Depdiknas }\end{array}$ & 25 \\
\hline 13 & 2002 & $\begin{array}{l}\text { Partisipasi Perempuan Dalam } \\
\text { Pembangunan Nagari }\end{array}$ & $\begin{array}{l}\text { Balitbangda } \\
\text { Sumbar }\end{array}$ & 40 \\
\hline 14 & 2002 & $\begin{array}{l}\text { Kajian pengembangan Pusat } \\
\text { Pelayanan terpadu Pemberdayaan } \\
\text { Perempuan dan Anak (Pt2TP2A) } \\
\text { Sumbar }\end{array}$ & Meneg PP RI & 20 \\
\hline 15 & 2002 & $\begin{array}{l}\text { Anak Perempuan Antara Harapan } \\
\text { dan Kenyataan: Dinamikan } \\
\text { Kehidupan Anak Jalanan } \\
\text { Perempuan di Kota Padang }\end{array}$ & DP2M Dikti & 10 \\
\hline 16 & 2001 & $\begin{array}{l}\text { Keterlibatan Perempuan dalam } \\
\text { Pemasaran Hasil Tani Komersial di } \\
\text { Pasar Padang Luar }\end{array}$ & DIPA UNP & 5 \\
\hline 17 & 2001 & $\begin{array}{l}\text { Perkembangan Usaha Wanita } \\
\text { Pengrajin Bordir dan Sulaman di } \\
\text { Desa Naras Hilir 2000 }\end{array}$ & DIPA UNP & 5 \\
\hline 18 & 2000 & $\begin{array}{l}\text { Sikap dan Prilaku Remaja Kota } \\
\text { Padang Terhadap PMS dan } \\
\text { HIV/AIDS dari perspektif Gender }\end{array}$ & DIPA UNP & 5 \\
\hline
\end{tabular}

\section{Pengalaman Pengabdian Kepada Masyarakat}

\begin{tabular}{|l|l|l|l|l|}
\hline No & Tahun & $\begin{array}{l}\text { Judul Pengabdian Kepada } \\
\text { Masyarakat }\end{array}$ & \multicolumn{2}{|c|}{ Pendanaan } \\
\cline { 4 - 5 } & 2012 & $\begin{array}{l}\text { Peningkatan Pengembangan Materi } \\
\text { Rembelajaran bagi Guru PPKn di } \\
\text { Kabupaten Solok }\end{array}$ & IDB & 10 \\
\hline 1 & 2012 & $\begin{array}{l}\text { Sosialisasi UU No 23 tahun 2004 } \\
\text { Tentang Penghapusan KDRT }\end{array}$ & Pribadi & \\
\hline 3 & 2003 & $\begin{array}{l}\text { Peningkatan Pengetahuan dan } \\
\text { pemahaman remaja terhadap PMS } \\
\text { dan HIV/AIDS }\end{array}$ & DIPA UNP & 5 \\
\hline
\end{tabular}


E.Pengalaman Peñilisan Artiké Hmiah daham Jurial dalam 5 Tahun terakhir

\begin{tabular}{|l|l|l|l|}
\hline No & Judul Artikel Ilmiah & Volume/No/Tahun & Nama Jurnal \\
\hline & $\begin{array}{l}\text { Fenomena Kekerasan terhadap } \\
\text { Perempuan Dalam Rumah } \\
\text { Tangga (Pandangan Mubaiig) }\end{array}$ & $\begin{array}{l}\text { Vol VI Nomor 2 } \\
\text { Desember 2012 }\end{array}$ & Jurnal Humanus \\
\hline $\begin{array}{l}\text { Representasi Permpuan dalam } \\
\text { Lembaga Legislatif di Sumatra } \\
\text { Barat Pasca Quota 30\%. } \\
\text { Representasi Permpuan dalam } \\
\text { Lembaga Legislatif di Sumatra } \\
\text { Barat Pasca Quota 30\%. }\end{array}$ & $\begin{array}{l}\text { Vol IV Nomor 1 April } \\
2005\end{array}$ & Jurnal Demokrasi \\
\hline $\begin{array}{l}\text { Kembali Ke Nagari: Kondisi dan } \\
\text { Posisi Perempuan Minangkabau } \\
\text { dalam Masyarakat Yang }\end{array}$ & jurnal PPIM Vol 2 & Jurnal PPIM \\
Berubah & $\begin{array}{l}\text { Dember 2004 } \\
\text { Kesetaraan Gender: Langkah } \\
\text { Menuju Demokratisasi di Nagari }\end{array}$ & Aoli II, Nomor 1 & Juril 2003 \\
\hline $\begin{array}{l}\text { Guru Sekolah Dasar Sebagai } \\
\text { Agen Sosialisasi Kesetaraan } \\
\text { Gender }\end{array}$ & Nomor 02 tahun & 2001, Juni 2001 & Buletin \\
\hline
\end{tabular}

Semua data yang saya isikan dan tercantum dalam biodata ini adalah benar dan dapat dipertanggungjawabkan secara hukum. Apabila di kemudian hari ternyata dijumpai ketidaksesuaian dengan kenyataan, saya sanggup menerima resikonya.

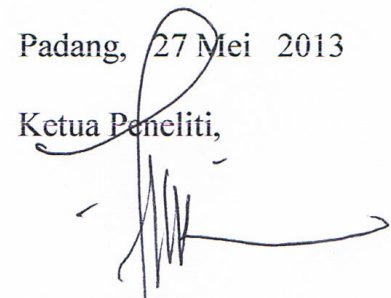

Dr. Fatmariza.H. M.Hum NIP.196603041991032001 


\section{KEMENTERIAN PENDIDIKAN DAN KEBUDAYAAN RI}

UNIVERSITAS NEGERI PADANG

1. Prof. Dr. Hamka Air Tawar Padang 25131 Telp.(0751)7051260, Fax.90751)7055628 email: info@unp.ac.id. Homepage: http://www.unp.ac.id/

\section{SURAT PERNYATAAN}

Yang bertanda tangan di bawah ini:

$\begin{array}{ll}\text { Nama } & \text { : Drs. Suryanef, M.Si. } \\ \text { NIP/NIDN } & : 196406061991031006 / 0006066407 . \\ \text { Pangkat/Golongan } & : \text { Pembina Tingkat I/IVb. } \\ \text { Jabatan fungsional } & : \text { Lektor Kepala. } \\ \text { Alamat } & : \text { Komplek Perumahan Pondok Pinang Blok C No.16 } \\ & \text { Lubuk Buaya, Padang 25173, Telpon 0751-482731. }\end{array}$

dengan ini menyatakan bahwa proposal penelitian saya dengan judul Pengembangan Model Pendidikan Perilaku Memilih (Voter's Education) Bagi Pemilih Pemula dalam Membangun Rasionalisasi Perilaku Memilih di Kota Padang yang diusulkan dalam skim penelitian Hibah Bersaing untuk tahun anggaran 2014 bersifat original dan belum pernah dibiayai oleh lembaga/sumber dana lain.

Bilamana di kemudian hari ditemui ketidaksesuaian dengan pernyataan ini, maka saya bersedia dituntut dan diproses sesuai dengan ketentuan yang berlaku dan mengembalikan seluruh biaya penelitian yang sudah diterima ke kas negara.

Demikian pernyataan ini dibuat dengan sesungguhnya dan dengan sebenar-benarnya.
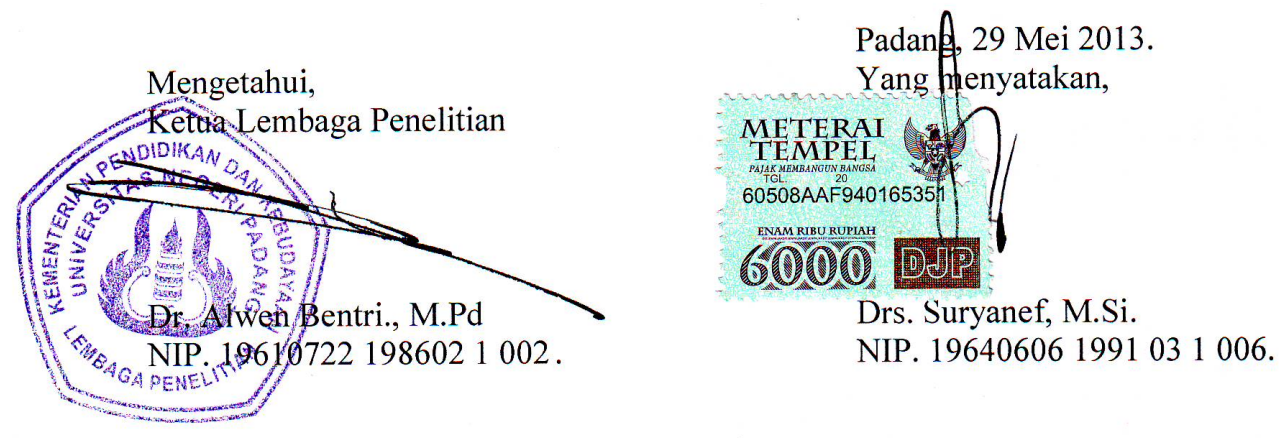